\title{
Speech Mechanism Screening Test for Children: An Evaluation of Performance in 3- to 12-Year-Old Normal Developing Children
}

\author{
Jaeock Kim ${ }^{\mathrm{a}}$, Moonja Shin ${ }^{\mathrm{b}}$, Yun Kyung Song ${ }^{\mathrm{c}}$ \\ ${ }^{a}$ Division of Speech Pathology Education, Graduate School of Education, Kangnam University, Yongin, Korea \\ ${ }^{b}$ Department of Speech-Language Pathology, College of Health Sciences, Chosun University, Gwangju, Korea \\ 'Department of Communication Disorders, College of Health, Welfare and Education, Tongmyong University, Busan, Korea
}

Correspondence: Jaeock Kim, PhD Department of Speech Pathology Education, Graduate School of Education, Kangnam University, 40 Gangnam-ro, Giheung-gu, Yongin 16979, Korea Tel: +82-31-280-3221

Fax: +82-31-280-3479

E-mail: jaeock@gmail.com

Received: October 10, 2017

Revised: January 17, 2018

Accepted: January 25, 2018

This work was supported by National Research Foundation of Korea Grant funded by the Korean Government (No. NRF-2013S1A5A8025388) and included some contents from the paper presented in 2015 at the 4th Joint Conference of the Korean Academy of Speech-Language and the Audiology and the Korean Speech-Language and Hearing Association.

\begin{abstract}
Objectives: The purpose of this study was to establish standardized scores for the Speech Mechanism Screening Test for Children (SMST-C). Methods: Two hundred thirty-six normal developing children (111 boys and 125 girls) from 3 to 12 years of age were included in the study. They were examined with the SMST-C, which yields a total score from three sub-systems: structure/function, phonation/voice/articulation, and diadochokinesis (DDK)/maximum phonation time (MPT)/speech rate/DDK rate. DDK rate consists of alternative motion rates (AMR) of 5 syllables $\left(/ \mathrm{p}_{\mathrm{N}} /, / \mathrm{t} \mathrm{N} /, / \mathrm{k \Lambda} /, / \mathrm{L} / /\right.$, and $\left./ \mathrm{k} \wedge \mathrm{n} /\right)$ and sequential motion rate (SMR) of /pstsks/. Results: The total score of SMST-C was not significantly different according to age or gender. MPT and speech rate significantly increased with age. DDK rates in all syllables for AMR and SMR also increased with age. In addition, AMR of / $\mathrm{t}_{\mathrm{N}} /$ (alveolar sound) was the fastest syllable among all mono-syllables and AMR of $/ \mathrm{k} \wedge \mathrm{n} /$ (velar sound) was the slowest. Conclusion: The results of this study provided normative data for speech mechanisms of children using SMST-C. SMST-C would be helpful for speech-language pathologists and other related professionals to screen for children with abnormal speech mechanisms.
\end{abstract}

Keywords: Speech mechanism screening test for children, Maximum phonation time, Speech rate, Diadochokinetic rate
말을 산출하기 위해서는 호흡, 발성, 조음 및 공명에 관여하는 기 관 간의 협응이 요구된다. 호흡기관은 기류를 형성하는 동력원 (power)이 되며, 발성기관은 호흡기관으로부터 생성된 기류에 의 한 성대 진동을 통해 '소리’의 음향학적 에너지를 산출하는 음원 (source)이 되고, 음향학적 에너지가 인두, 연구개, 경구개, 혀, 치조, 치아, 입술 및 비강과 같은 조음기관과 공명기관을 통과하면서 여 과(filter) 과정을 거쳐 '말소리'로 산출되면서 사람 간의 의사소통 이 가능하게 된다. 이 기관들의 구조나 기능의 이상 또는 이들 간의 불협응이 초래될 경우 의사소통의 어려움이 발생할 수 있다. 따라 서 언어치료 임상현장에서 의사소통과 관련된 문제를 평가하기 위 해서는 일차적으로 말 산출에 관여하는 기관들의 구조와 기능의 이상 여부뿐 아니라 이들 간의 협응이 조화롭게 이루어지는지를
살펴보아야 한다. 이를 통해 의사소통의 문제를 치료하고 진행이나 악화되는 것을 예방하기 위한 치료계획을 보다 구체적이고 체계적 으로 수립할 수 있고, 치료효과를 판단하는 근거 자료로 이용할 수 있다.

현재 국내에서 호흡, 발성, 조음 및 공명에 관여하는 기관(이하 조음기관)의 구조와 기능을 평가하는 검사도구로는 만 18-59세의 조음장애나 언어장애가 없는 정상 남녀 성인을 대상으로 표준화한 조음기관 구조.기능 선별검사(Speech Mechanism Screening Test, SMST; Shin, Kim, Lee, \& Lee, 2009)가 유일하다. SMST는 조음기관 의 구조나 기능의 이상 여부를 평가하는 '조음기관의 구조와 기능' 영역과 함께 조음기관들의 협응 과정을 평가하기 위한 ‘발성·음성. 조음선별' 및 조음기관을 가능한 빠르게 움직이도록 하여 조음기 
관을 구성하는 근육들의 최대 운동속도 및 규칙성과 정확성을 평 가하는 '조음교대운동(diadochokinesis, DDK)'의 세 영역으로 구 성되어 있다. 또한 모음연장발성 시의 최대발성지속시간(maximum phonation time, MPT)을 측정하여 폐활량과 폐내 압력 및 성대의 접촉양상 그리고 성대를 통과하는 기류의 양과 압력 등을 간접적 으로 평가할 수 있으며(Kent, Kent, \& Rosenbek, 1987), 말속도, 조 음오류 및 교대운동속도(alternating motion rate, AMR)와 일련운 동속도(sequential motion rate, $\mathrm{SMR}$ )를 측정하여 조음 산출 시 기 능이나 신경계 협응체계의 이상 유무를 선별하고, 각 영역의 검사 항목을 점수화하여 연령 규준별로 평균, 표준편차 및 기준점수를 제시함으로써 이에 대상자의 수행을 비교할 수 있다.

그러나 SMST의 총점수 및 다른 결과치들은 성인에서 표준화된 것으로 성인과는 구조와 기능에 있어 차이가 있고 연령 증가에 따 라 지속적인 발달과정에 있는 아동의 조음기관 이상 유무를 판별 하기는 어렵다. 또한 SMST에서 제시하는 검사방법과 과제는 아동 을 평가하기에 적합하지 않을 수 있다. 가령, 아동 치아의 맹출 시기 나 교합, 구개의 특성 등은 성인과 상당한 차이가 있으므로 이를 고 려하여 아동의 조음기관의 구조와 기능을 살펴보아야 하며, SMST 에서 사용된 문장 읽기 과제는 읽기가 어려운 취학 전 아동들이 수 행하기 불가능하기 때문에 음성이나 조음평가를 위한 다양한 과제 의 개발이 요구된다. 따라서 아동의 발달과정을 고려하고 아동에 게 적합한 검사방법과 과제를 중심으로 한 평가가 이루어져야 한 다. 특히 성인에 비해 아동을 중심으로 의사소통장애의 평가와 중 재가 많이 실시되고 있는 국내 언어치료 임상현장의 상황을 고려 할 때 아동의 조음기관 구조와 기능을 평가할 수 있는 검사도구의 개발이 더욱 요구되어져 왔다. 이에 본 연구진은 SMST를 기본 토대 로 하여 국내·외 검사도구, 문헌 조사 및 인터넷 검색을 통해 관련 된 자료들을 수집 분석하고 정리하여 아동의 조음기관 구조와 기 능을 평가하기에 적합한 검사도구를 제작하였으며, 이를 '아동용 조음기관의 구조 및 기능 선별검사(SMST-C)'라고 명칭하였다. 예 비연구(Kim \& Kim, 2016)를 통해 5명의 언어병리학과 교수와 10 년 이상의 임상경력이 있는 2 명의 언어재활사로부터 2 차에 걸쳐 검 증한 내용타당도는 5 점 만점에 4.57점으로 매우 높았으며, 전체 대 상자의 $23 \%$ 에 해당하는 15 명의 자료를 재분석하여 실시한 평가자 내 및 평가자 간 신뢰도 계수는 모든 항목에서 .955 이상으로 유의 하게 높았다.

SMST-C는 기존 SMST의 '조음기관의 구조와 기능' '발성·음성. 조음선별' 및 '조음교대운동'의 세 하위 분류체계 및 MPT, 말속도, $\mathrm{DDK}$ 속도(AMR, SMR)를 그대로 사용하였다. '조음기관의 구조와 기능'은 ‘조음기관 구조.기능'으로 간략하게 명칭을 변경하였고, 한
번의 지시로 여러 항목들을 한꺼번에 검사할 수 있도록 항목들이 배치되어 있다. SMST의 항목들 중 불필요하거나 측정이 어려운 부 분은 삭제하였고(예: 혀를 내밀고 말아서 좁히기, 인두벽과 인두협 부의 색깔 및 크기 등), 일부 항목은 추가(예: 얼굴의 불수의적 운 동, 혀의 근력 등)하였으며, 각 항목별 지시사항도 아동에게 적합하 도록 수정하였다. 또한 평가자가 보다 정확하게 점수를 부여할 수 있도록 점수 기준을 보다 명확하게 제시하였다. 가령, 치아나 치열 상태의 경우에는 아동의 맹출 시기를 고려한 연령별 치아의 개수 나 치아 상태 등에 따른 점수 기준을 제시하였다. '발성·음성·조음 선별’에서는 학령전기와 학령기로 구분하여 학령전기 아동용으로 12 개의 단어들로 구성된 그림카드를 제작하여 단어 수준의 어두 초성에서 모든 자음의 조음오류를 선별하도록 하였고, 학령기 아 동은 성인과 동일하게 문장의 읽기카드를 사용하여 /리, /시, /ㅈ/ / 의 조음오류만을 선별하도록 하였으며, 아동의 조음발달 수준을 고려하기 위해 자음습득연령 $(90 \%$ 아동이 습득하는 자음) (Kim, 1996; Kim \& Pae, 2005)을 제시하여 해당 연령에 따른 조음오류 여 부를 판단하도록 하였다. 또한 SMST에서는 조음선별이 점수화되 지 않았기 때문에 SMST-C에서는 제시된 12 개의 자음 중 한 개의 음소라도 대치/생략(0점) 또는 왜곡(1점)된 경우 0 점 또는 1 점을 부 여하여 0-2점으로 점수화하고 음성과 같이 2 배의 가중치를 두어 산출하도록 하였다. '조음교대운동은 SMST의 6 개의 일음절들 중 아동이 반복하여 산출하기 어려워하는 / / / 모음을 제외하고 자음 에/ / / 모음을 결합한 5 개 무의미 일음절의 AMR을 측정하였다. 말 속도의 경우는 읽기가 가능한 6-12세의 아동에서 측정하도록 하였 다. SMST와 SMST-C의 각 항목과 점수체계는 Appendix 1에 제시 되어 있다.

만 3-6세 아동 65명(남아 30명, 여아 35명)의 정상발달 아동을 대 상으로 SMST-C를 사용하여 아동의 조음기관 구조와 기능 특성을 살펴본 예비연구(Kim \& Kim, 2016)에 따르면, 총점수, MPT 및 $\mathrm{SMR}$ 은 성별과 연령에 따라 차이가 없었으며, $\mathrm{AMR}$ 은 성별에 따른 차이는 없었으나 연령에 따라 대부분의 일음절에서 3 세와 다른 연 령들 간에 유의한 차이를 보였고, 그 외 다른 연령 간에는 차이가 없었다. 이 연구에서는 유치열기인 학령전기 아동만을 대상으로 하 였기 때문에 조음에 영향을 미칠 수 있는 중절치(앞니)와 치아의 교 합 상태를 살펴보는데, 기준이 되는 대구치(어금니) 또는 견치(송곳 니)가 완전히 맹출되지 않은 시기라서 조음이나 교합상태 이상 여 부를 명확하게 선별하기 어려울 수 있다. 또한 유치열로 인해 구개 의 크기와 용적이 영구치가 맹출한 학령기 아동이나 성인과는 상 이하게 다를 수 있다. 이와 더불어 글을 읽지 못하는 연령이 대부분 포함되었기 때문에 그림카드만을 이용하여 조음선별을 실시하였 
고, 말속도 또한 측정되지 않았다. 따라서 SMST-C를 아동을 대상 으로 임상현장에서 사용하기 위해서는 학령기 아동을 포함한 전 체 아동을 대상으로 측정할 필요가 있으며, 성별과 연령별로 보다 세분화된 정상 기준을 제시하는 표준화된 점수체계가 필요하다.

이에 본 연구는 아동 계층의 조음기관 구조 및 기능을 수량화하 여 평가하기 위해 제작된 SMST-C를 학령전기와 학령기 정상아동 을 대상으로 실시하고, 성별과 연령별로 정상 범위를 수량화하여 제시함으로써 임상현장에서 아동의 조음기관의 구조와 기능을 보 다 손쉽게 살펴볼 수 있는 검사도구의 표준화 작업을 수행하고자 하였다.

\section{연구방법}

\section{연구대상}

서울·경기, 광주 및 부산에 거주하고 신체적·정신적으로 정상 발달 과정에 있으며, 언어나 조음의 이상이 없는 만 3-12세 아동 236명(남아 111, 여아 125)을 대상으로 하였다. 이 중 서울. 경기는 134 명(남아 61, 여아 73), 광주는 48명(남아 26, 여아 22), 부산은 54 명(남아 24 , 여아 30)이었다. 언어나 조음의 이상 유무는 일차적으 로 주 양육자나 아동이 재학 중인 어린이집, 유치원 또는 학교 교사 와의 면담으로 평가하였고, 5 년 이상의 임상경력이 있는 2 급 언어 재활사 2명이 수용-표현어휘력검사(Receptive \& Expressive Vocabulary Test, REVT; Kim, Hong, Kim, Jan, \& Lee, 2009), 우리말 조음·음운평가(Urimal Test of Articulation and Phonology, UTAP; Kim \& Shin, 2004)의 낱말수준 검사 및 “이름, 연령, 유치원/ 학교 반”을 산출하게 하여 아동의 자발화를 평가하였다. REVT 와 U-TAP상에서 -1 SD 이하이거나 자발화상에서 언어나 조음의 이상이 있다고 의심되는 대상자는 본 연구에서 제외하였다. 또한 검사에 비협조적이거나 검사를 완료하지 못한 경우 및 중복장애, 구개파열, 청각장애 등의 조음기관 구조와 기능의 이상을 초래할 가능성이 있는 아동과 조음의 오류를 보일 수 있는 다문화가정의 아동 및 치아교정 중인 아동은 제외하였다. 성별과 연령에 따른 대 상자 분포는 Table 1에 제시하였다. 연령에 따른 성별의 빈도수 차 이를 $\chi^{2}$ 검정으로 분석한 결과, 연령에 따른 성별 간 빈도수는 유의 한 차이가 없었다 $\left(\chi^{2}=7.293, p=.607\right)$.

\section{검사도구}

아동의 조음기관 구조 및 기능을 살펴보기 위해 선행연구(Kim \& Kim, 2016)를 통해 개발되고 신뢰도와 타당도가 검증된 SMST$\mathrm{C}$ 를 사용하였다(Appendix 1).
Table 1. Distribution of participants

\begin{tabular}{lccc}
\hline Age $(\mathrm{yr})$ & Male & Female & Total \\
\hline 3 & 9 & 11 & 20 \\
4 & 20 & 11 & 31 \\
5 & 11 & 23 & 34 \\
6 & 13 & 16 & 29 \\
7 & 9 & 12 & 21 \\
8 & 11 & 13 & 24 \\
9 & 10 & 9 & 19 \\
10 & 11 & 12 & 23 \\
11 & 10 & 11 & 21 \\
12 & 7 & 7 & 14 \\
Sum & 111 & 125 & 236 \\
\hline
\end{tabular}

SMST-C의 산출 가능한 총점수는 0-100점으로, 점수가 낮을수 록 조음기관의 구조 및 기능이 정상적이지 않음을 의미한다.

\section{자료수집}

SMST-C는 아동이 재학 중인 어린이집/유치원 또는 집의 조용한 방에서 임상경력이 5 년 이상인 2 급 언어재활사 1 명이 아동과 일대 일로 마주보고 앉아서 아동에게 본 검사에 대한 간단한 설명을 하 고 진행하였다. 다만, 광주와 부산에서의 자료 수집은 언어치료학 과에 재학 중인 '언어재활진단평가' 수업을 2학점 이상 이수한 학부 4 학년 또는 대학원의 석/박사 과정생들에게 점수부여 방식에 관한 그림을 포함한 PPT 자료를 배부하고, 2 회에 걸쳐 검사방법을 훈련 한 후(지역별 전체 교육 1 회, 개별 교육 1 회) 2 명씩 짝을 이루어 함께 검사를 실시하도록 하였다. '조음기관 구조.기능’을 살펴보기 위해 이비인후과용 구강경, 펜라이트 및 설압자를 사용하였고, ‘발성·음 성·조음선별'과 ‘조음교대운동'에서 $\mathrm{MPT}$, 음성, 말속도 및 $\mathrm{DDK}$ 속 도 측정을 위해초시계를 사용하였으며, 휴대용 녹음기인 Sony PCMD50 또는 휴대폰 녹음기로 이들을 녹음하여 자료 분석 및 신뢰도 분석을 실시하였다.

본 연구는 선행연구(Kim \& Kim, 2016)에서 실시한 방법과 동일 한 방법으로 자료를 수집하였다. 아동에게 SMST-C의 '조음기관 구조.기능 7 개 영역을 평가하기 위해 항목별로 실시하고 해당 점 수를 책정하였다. 또한 각 항목별 점수뿐 아니라 구조나 기능의 특 성상 이상이나 특이사항이 있는 경우 비고란에 별도로 기록하고 추가적인 부모와의 상담 내용을 기록하였다. '발성·음성·조음선 별'을 평가하기 위해 아동에게 “나는 OOO어린이집/유치원/학교 $\mathrm{OOO}$ 반 $\mathrm{OOO}$ 입니다.”라고 자신을 소개하게 한 후 “숨을 최대한 크게 들이마시고 방금 말한 것처럼 편안한 목소리로 /아/ 소리를 최 대한 길게 내세요.”라고 지시하였다. 검사자가 시범을 보이고 아동 
이 1-2회 반복하여 연습한 후에 이를 실시하였고, 이 과정에서 $\mathrm{MPT}$ 와음성을 측정하였다.MPT는 3회 반복 측정치 중 최대 측정 치를 사용하였다. 또한 조음선별을 위해 아동에게 그림카드를 제시 하여 각 그림에 해당하는 단어를 산출하도록 하였으며 산출된 발 화는 녹음하였다. '조음교대운동'을 위해 측정한 DDK 속도는 아동 에게 각 음절을 최대한 정확하고 빨리 말하도록 하여 측정하였다. 본 검사를 실시하기 전에 검사자가 1-2회 시범을 보이고 아동이 몇 차례 연습을 하게 하였다. AMR은 /퍼/, /터/, /커/, /러/, /겅/의 각 일 음절을 5 초간 최대한 빠르고 정확하게 반복하여 조음하는 횟수를 측정한 후, 이를 1 초 동안에 조음한 횟수로 계산하였고, SMR도/퍼 터커/를 5 초간 최대한 빠르고 정확하게 반복하여 조음하는 횟수를 1 초 동안 조음한 횟수로 계산하였다. AMR과 SMR은 각 음절별로 2 회씩 측정한 것의 평균값을 산출하였다. 다만, 연령이 어린 아동의 경우 $\mathrm{DDK}$ 를 충분히 연습한 후에도 해당 연령에서 산출될 수 없는 자음을 제외하고 정조음이 가능하지 않은 경우에 조음정확성에 0 점 또는 1 점을 할당하였다. 아동의 MPT와 DDK 속도를 녹음한 음 성파일은 Cool Edit Pro v2.1 (Syntrillium, Phoenix, AZ, USA)을 이용하여 각 과제별 및 음절별로 분리하여 저장하였다. 음성파일 의 분석은 $\mathrm{MPT}$ 의 경우 연속된 음성파형의 시작점과 끝 지점 사이 의 시간을 측정하였고, $\mathrm{DDK}$ 속도는 각 음성파일을 반복적으로 청 취하여 음절수를 세고, 음성파형의 시작점부터 5 초간 에너지가 커 진 음절수를 센 후 이들 간의 수치가 일치하는지 확인하여 5 초간 산출된 음절수를 계산한 후 다시 1 초당 산출한 음절수로 환산하였 다. 다만, $\mathrm{DDK}$ 측정 중간에 숨을 쉰다거나 휴지가 있는 경우에는 이 부분을 음성파형에서 삭제한 후 분석하였다.

신뢰도 검정을 위해 본 연구에 참여한 전체 아동의 $10 \%$ 에 해당 하는 26 명 아동의 자료를 재분석하였다. '조음기관 구조.기능'은 담 임교사나 부모의 허락하에 비디오를 촬영한 자료를 이용하였으며, ‘발성·음성·조음선별'과 '조음교대운동'은 녹음한 음성파일을 재 분석하였다. 이를 위해 주검사자가 2번 반복하여 평가함으로써 평 가자 내 신뢰도를 분석하였고, 주검사자와 임상경력이 10 년 이상인 2 급 언어재활사 한 명이 아동을 동시에 평가하여 Pearson 상관분석 을 이용하여 평가자 간 신뢰도를 산출하였다. 평가자 내 신뢰도는 총점수가.970 ( $p<.001), \mathrm{MPT}$ 가.998 ( $p<.001)$, DDK 속도가.9801.000 ( $p<.001)$ 이었으며, 평가자간 신뢰도는 총점수가. 982 ( $p<.001)$, MPT가. 980 ( $p$ <.001), 말속도가. 990 ( $p<.001)$, DDK 속도가 .852.992 ( $p$ <.001)로 유의하게 높은 정적 상관관계를 보였다.

\section{자료분석}

수집된 자료는 IBM SPSS Statistics version 24.0 프로그램(IBM,
Armonk, NY, USA)으로 통계 처리하였다. SMST-C의 '조음기관 구 조.기능' 점수, 음성과 조음선별로 구성된 '발성·음성·조음선별' 점수, 조음규칙성과 조음정확성으로 구성된 '조음교대운동' 점수 및 이들을 모두 합한 총점수의 평균과 표준편차를 성별과 연령별로 산출하였다. 또한 발성의 MPT, 말속도 및 DDK 속도(AMR, SMR) 의 평균과 표준편차를 성별과 연령별로 산출하였다. 총점수, MPT, 말속도 및 DDK 속도의 성별과 연령에 따른 차이는 이원분산분석 (two-way ANOVA)으로 비교하였으며, 유의한 차이가 있는 경우 Bonferroni 사후검정을 실시하였다. 일음절 간 AMR의 성별과 연령 에 따른 차이를 비교하기 위해 성별과 연령별을 집단 간 차이로 하 고, 음절을 집단 내 차이로 하는 반복측정 혼합분산분석(repeated measures mixed ANOVA)을 실시하였다. 집단 간(연령별)에 유의 한 차이가 있을 경우 Bonferroni 사후검정을 실시하고, 집단 내(일 음절)에 유의한 차이가 있을 경우에는 주효과 분석을 실시하였다.

\section{연구결과}

\section{SMST-C 총점수}

SMST-C의 '조음기관 구조.기능'의 구조와 기능 점수, '발성·음 성·조음선별'의 음성과 조음선별 점수, '조음교대운동'의 조음규칙 성과 조음정확성 점수 및 총점수의 성별과 연령별 평균과 표준편 차는 Appendix 2에 제시하였다.

'조음기관 구조.기능' 점수의 전체 평균이 56.84 점 $(\mathrm{SD}=2.80)$ 으 로, 남아가 56.80점 $(\mathrm{SD}=2.82)$, 여아가 56.87점 $(\mathrm{SD}=2.79)$ 이었다. 성별과 연령별에 따른 차이를 비교한 결과, 성별과 연령별 상호작용 및 성별에 따른 차이는 없었으나 연령에 따라 유의한 차이가 나타 났다 $(F=3.331, p=.001)$. 그러나 사후검정 결과 유의한 차이가 있 는 연령군들은 없었다.

‘발성·음성·조음선별’의 음성과 조음선별 점수의 전체 평균은 15.12 점 $(\mathrm{SD}=1.52)$ 이었고, 남아가 15.06 점 $(\mathrm{SD}=1.47)$, 여아가 15.17 점 $(\mathrm{SD}=1.57)$ 으로 성별과 연령별 상호작용 및 성별이나 연령에 따 른주효과가 나타나지 않았다.

'조음교대운동'의 조음규칙성과 조음정확성 점수의 전체 평균은 23.66점 $(\mathrm{SD}=0.77)$, 남아는 23.62점( $\mathrm{SD}=0.89)$, 여아는 23.70점(SD $=0.65)$ 으로 성별과 연령별 상호작용이 유의하게 나타났다 $(F=2.984$, $p=.002$ ). Figure 1 은 DDK 점수의 성별과 연령별 분포를 나타낸다.

총점수의 전체 평균은 95.62 점 $(\mathrm{SD}=3.37)$ 이었고, 남아가 95.49 점 $(\mathrm{SD}=3.26)$, 여아가 95.74 점 $(\mathrm{SD}=3.47)$ 으로 성별과 연령별 상호작 용이 나타났다 $(F=2.135, p=.028)$. Figure 2 는 총점수의 성별과 연 령별 분포를 보여준다. 


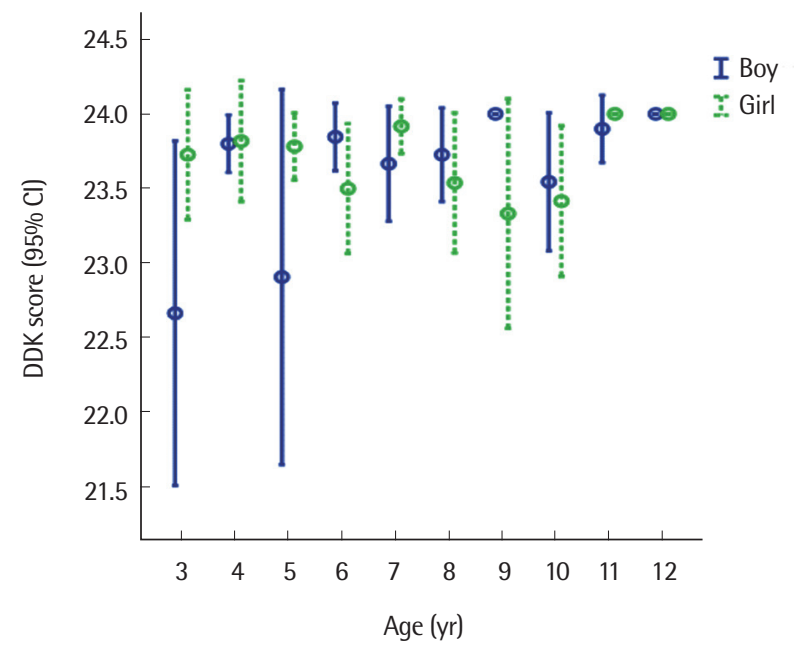

Figure 1. Diadochokinesis (DDK) score of Speech Mechanism Screening Test for Children (SMST-C) by age. Error bar represents the standard deviation of the data.

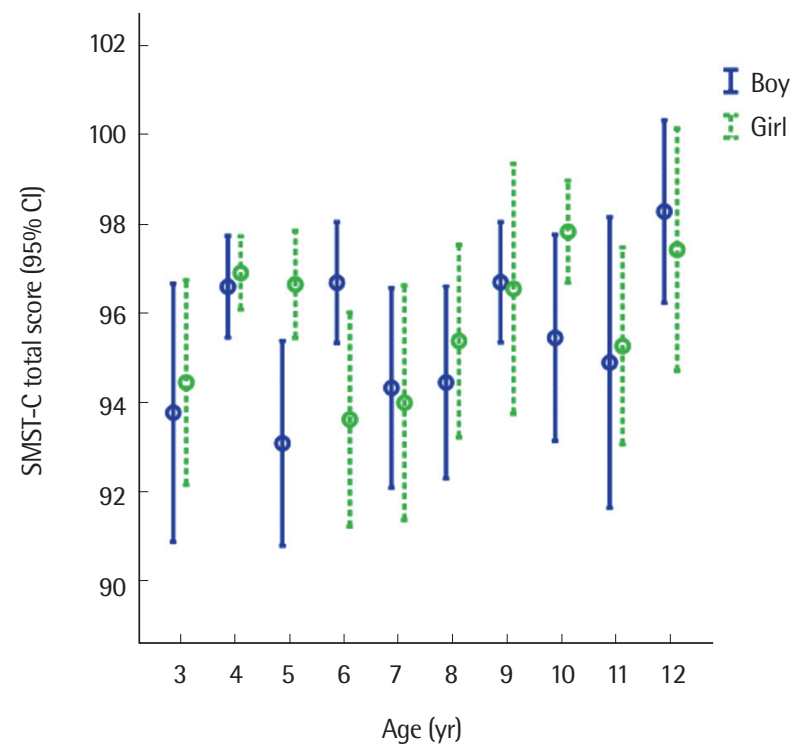

Figure 2. Total score of Speech Mechanism Screening Test for Children (SMST-C) by age. Error bar represents the standard deviation of the data.

\section{MPT}

MPT의 성별과 연령별 평균과 표준편차는 Appendix 3에 제시하 였다. MPT의 전체 평균은 11.69 초 $(\mathrm{SD}=5.89)$ 였고, 남아와 여아가 각 11.98 초 $(\mathrm{SD}=5.98)$ 와 11.43 초 $(\mathrm{SD}=5.83)$ 였다. 성별과 연령에 따 른 상호작용 및 성별에 따른 주효과는 없었으나 연령에 따라 유의 한 차이가 나타나 $(F=6.681, p=.001)$. 사후검정을 실시한 결과, 3 세 $(p=.003)$ 와 4 세 $(p<.05)$ 는 모두 9-12세의 각 연령과 유의한 차이를 보였고, 5 세는 11 세 $(p=.015)$ 및 12 세 $(p=.03)$ 와각각 유의한차이를 보였다. Figure 3은 연령에 따른 MPT의 95\% 신뢰구간 오차막대 도

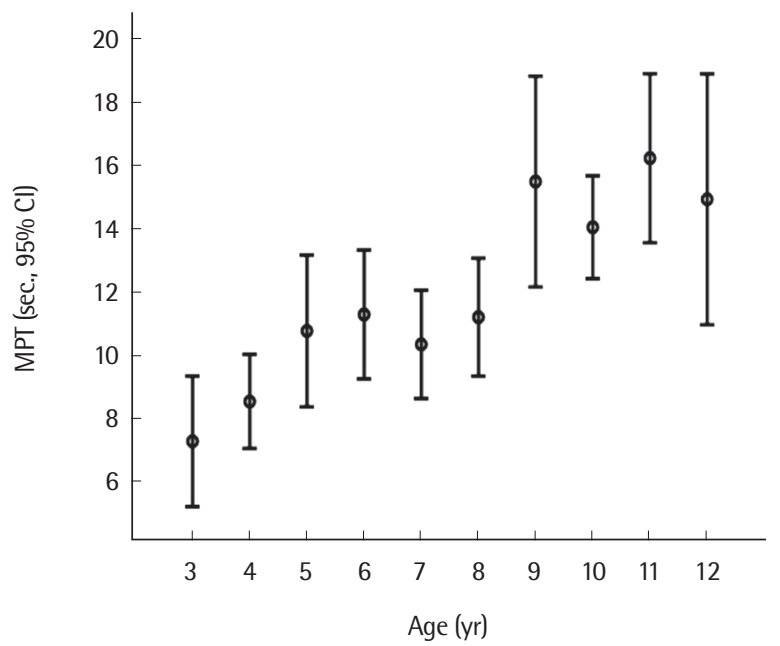

Figure 3. Maximum phonation time (MPT) by age. Error bar represents the standard deviation of the data.



Figure 4. Speech rate (syllables per second) by age. Error bar represents the standard deviation of the data.

표를 나타내며, 연령이 증가할수록 MPT는 증가하는 경향을 보인다.

\section{말속도}

말속도(초당 음절수)의 성별과 연령별 평균과 표준편차는 Appendix 3에 제시하였으며, 글을 읽을 수 있는 연령인 6세부터 실시 한 결과를 보여준다. 말속도의 전체 평균은 4.76 음절/초 $(\mathrm{SD}=1.09)$ 였고, 남아는 4.68 음절/초 $(\mathrm{SD}=1.10)$, 여아는 4.83 음절/초 $(\mathrm{SD}=1.09)$ 였다. 성별과 연령별 상호작용과 성별에 따른 차이는 없었으나 연령 에 따라 유의한 차이를 보였다 $(F=10.495, p<.001)$. 이에 실시한 사 

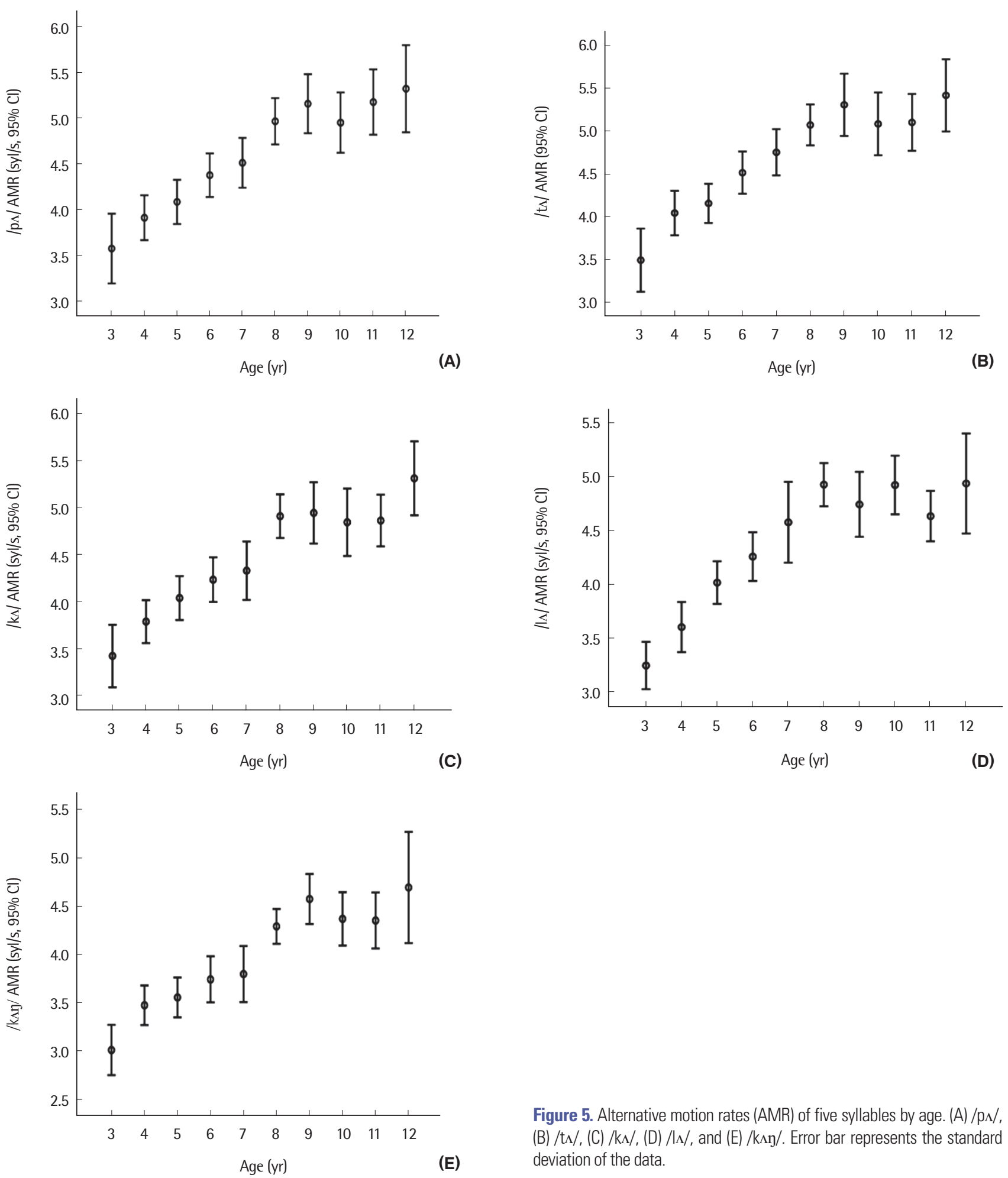

Figure 5. Alternative motion rates (AMR) of five syllables by age. (A) $/ \mathrm{p}_{\Lambda} /$, (B) $/ \mathrm{t}_{\Lambda} /$, (C) $/ \mathrm{k} \Lambda /$, (D) $/ \mathrm{L}_{\Lambda} /$, and (E) $/ \mathrm{k} \wedge \mathrm{y} /$. Error bar represents the standard deviation of the data.

후검정에서 6세는 9-12세의 각 연령과 유의한차이가 있었고 $(p<.005)$, 7세는 10-12세의 각 연령과 유의한 차이가 있었다 $(p<.05)$. 연령에
따른 초당 음절수의 말속도를 나타내는 Figure 4 에 따르면, 연령이 증가할수록 말속도(초당 음절수)가 증가한다. 


\section{DDK 속도}

$\mathrm{DDK}$ 속도는 /퍼/, /터/, /커/, /러/, /겅/의 5개 일음절의 AMR과/퍼 터커/의 SMR로 구성되며, $\mathrm{AMR}$ 과 $\mathrm{SMR}$ 의 초당 횟수를 성별과 연 령별로 Appendix 3에 평균과 표준편차를 제시하였다.

/퍼/의 AMR 전체 평균은 4.53 회/초(SD=0.88)였고, 남아는 4.58 회/초( $\mathrm{SD}=0.83)$, 여아는 4.48 회/초 $(\mathrm{SD}=0.92)$ 였다. 성별과 연령 간 상호작용이나 성별에 따른 유의한 차이는 없었으나 연령에 따라 유 의한 차이를 보였다 $(F=7.736, p<.001)$. 사후검정 결과, 3 세는 6-12 세의 각 연령( $p<.005)$ 과, 4 세는 $7-12$ 세의 각 연령 $(p<.05)$ 과, 5 세는 $8-12$ 세의 각 연령( $p<.001)$ 과, 6세는 9세, 11세, 12세의 각 연령 $(p<.01)$ 과 유의한 차이를 보이고. 연령이 증가할수록 /퍼/의 $\mathrm{AMR}$ 은 증가 한다(Figure 5A).

/터/의 AMR 전체 평균은 4.62 회/초 $(\mathrm{SD}=0.89)$ 였고, 남아는 4.70 회/초( $\mathrm{SD}=0.85)$, 여아는 4.55 회/초 $(\mathrm{SD}=0.93)$ 였다. 성별과 연령 간 상호작용이나 성별에 따른 유의한 차이는 없었으나 연령에 따라 유 의한차이를 보였다 $(F=16.926, p<.001)$. 사후검정 결과, 3 세는 5-12 세의 각 연령 $(p<.001)$ 과, 4 세는 7-12세의 각 연령 $(p=.009)$ 과, 5 세는 $7-12$ 세의 각 연령 $(p<.001)$ 과, 6 세는 9세( $p=.012)$ 및 12세( $p=.006)$ 와 유의한 차이를 보이며, 연령이 증가할수록 /터/의 AMR은 증가 한다(Figure 5B).

/커/의 AMR 전체 평균은 4.38 회/초( $\mathrm{SD}=0.85)$ 였고, 남아는 4.46 회/초( $\mathrm{SD}=0.78)$, 여아는 4.32 회/초 $(\mathrm{SD}=0.90)$ 였다. 성별과 연령 간 상호작용이나 성별에 따른 유의한차이는 없었으나 연령에 따라 유 의한 차이를 보였다 $(F=17.191, p<.001)$. 사후검정 결과, 3 세는 5-12 세의 각 연령( $p<.001)$ 과, 4 세는 $8-12$ 세의 각 연령 $(p<.001)$ 과, 5 세 는 8-12세의 각 연령 $(p<.01)$ 과 유의한 차이를 보였으며, 6세는 8세 $(p=.021), 9$ 세( $p=.004)$ 및 12세( $p<.001)$ 와 각각 유의한 차이를 보 였고, 7 세는 12 세와 유의한 차이를 보이고( $p=.001)$, 연령이 증가할 수록 /커/의 AMR이 증가한다(Figure 5C).

/러/의 $\mathrm{AMR}$ 전체 평균은 4.33 회/초 $(\mathrm{SD}=0.81)$ 였고, 남아는 4.33

Table 2. Comparison of alternative motion rates among monosyllables by gender and age

\begin{tabular}{|c|c|c|c|c|c|}
\hline & SS & $d f$ & MS & $F$ & $p$-value \\
\hline Syllable & 62.746 & 3.090 & 20.304 & 107.818 & $<.001$ \\
\hline Gender & 1.021 & 1 & 1.021 & .671 & .414 \\
\hline Age & 323.964 & 9 & 35.996 & 23.668 & $<.001$ \\
\hline Syllable×Gender & .428 & 3.090 & .139 & .736 & .534 \\
\hline Syllable×Age & 9.391 & 27.812 & .338 & 1.793 & .008 \\
\hline Gender $\times$ Age & 18.553 & 9 & 2.061 & 1.355 & .210 \\
\hline Syllable×Gender×Age & 4.449 & 27.812 & .160 & .849 & .690 \\
\hline
\end{tabular}

회/초( $\mathrm{SD}=0.77)$, 여아는 4.33 회/초 $(\mathrm{SD}=0.86)$ 였다. 성별과 연령 간 상호작용이나 성별에 따른 유의한 차이는 없었으나 연령에 따라 유 의한 차이를 보였다 $(F=20.223, p<.001)$. 사후검정 결과, 3세는 5-12 세의 각 연령 $(p<.001)$ 과, 4 세는 6-12세의 각 연령 $(p=.002)$ 과, 5 세 는 8-12세의 각 연령 $(p<.05)$ 과, 6 세는 8 세 $(p=.008), 9$ 세( $p=.009)$, 12 세 $(p=.042)$ 와 유의한 차이를 보였으며, 연령이 증가할수록 /러/ 의 $\mathrm{AMR}$ 은 증가하는 경향을 보인다(Figure $5 \mathrm{D})$.

/겅/의 AMR 전체 평균은 3.92회/초 $(\mathrm{SD}=0.77)$ 였고, 남아는 3.97 회/초 $(\mathrm{SD}=0.79)$, 여아는 3.88 회/초 $(\mathrm{SD}=0.76)$ 였다. 성별과 연령 간 상호작용이나 성별에 따른 유의한 차이는 없었으나 연령에 따라 유 의한 차이를 보였다 $(F=20.223, p<.001)$. 사후검정 결과, 3세는 6-12 세의 각 연령 $(p<.001)$ 과, 4 세는 $8-12$ 세의 각 연령 $(p<.001)$ 과, 5 세 는 8-12세의 각 연령 $(p<.002)$ 과, 그리고 6세는 9세( $p=.001), 10$ 세 $(p=.028), 12$ 세 $(p<.001)$ 와 유의한 차이를 보이고, 연령이 증가할 수록/겅/의 AMR은 증가한다(Figure 5E).

일음절 간 성별과 연령에 따른 $\mathrm{AMR}$ 의 차이를 비교한 결과, $\mathrm{Ta}-$ ble 2 와 같이 일음절, 성별, 연령 간의 상호작용은 없었고, 일음절과 성별, 성별과 연령, 성별에 따른 차이도 없었다. 그러나 일음절과 연 령 간의 상호작용 $(F=1.793, p=.008)$ 과 일음절 $(F=107.818, p<.001)$ 및 연령 $(F=23.668, p<.001)$ 에 따른 주효과가 유의하게 나타났으 며, 일음절과 연령 간의 상호작용은 Figure 6에서 살펴볼 수 있다. 연령에 따른 차이를 살펴보기 위해 실시한 사후검정 결과, 3 세는 $5-12$ 세의 각 연령 $(p<.001)$ 과, 4 세는 6-12세의 각 연령 $(p<.001)$ 과,

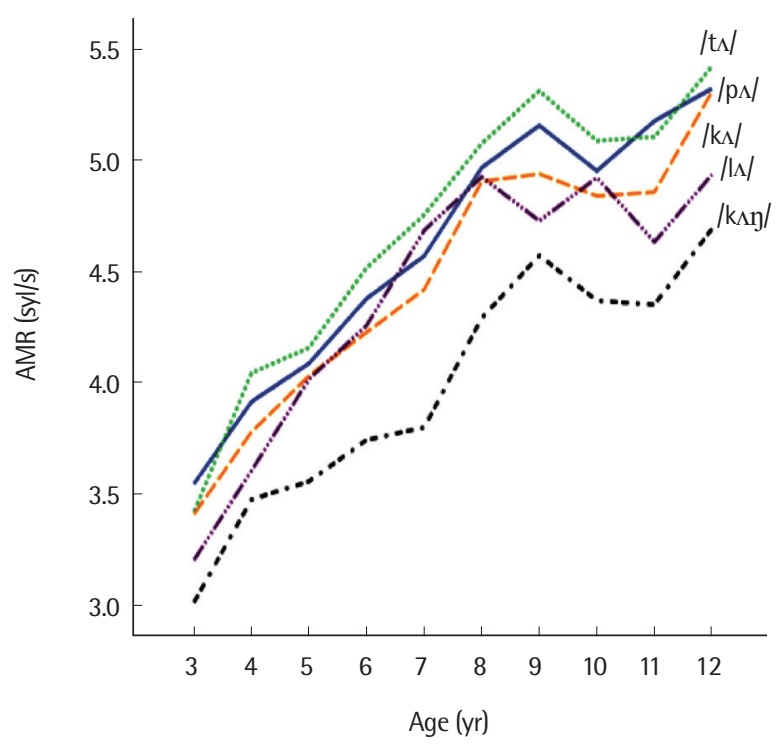

Figure 6. Comparison of alternative motion rates (AMR) of five syllables $(/ \mathrm{p} \Lambda /$, $/ \mathrm{t} \Lambda /, / \mathrm{k} /, / \mathrm{L}_{\mathrm{\Lambda}} /$, and $/ \mathrm{k} \wedge \mathrm{y} / \mathrm{l}$ by age. 


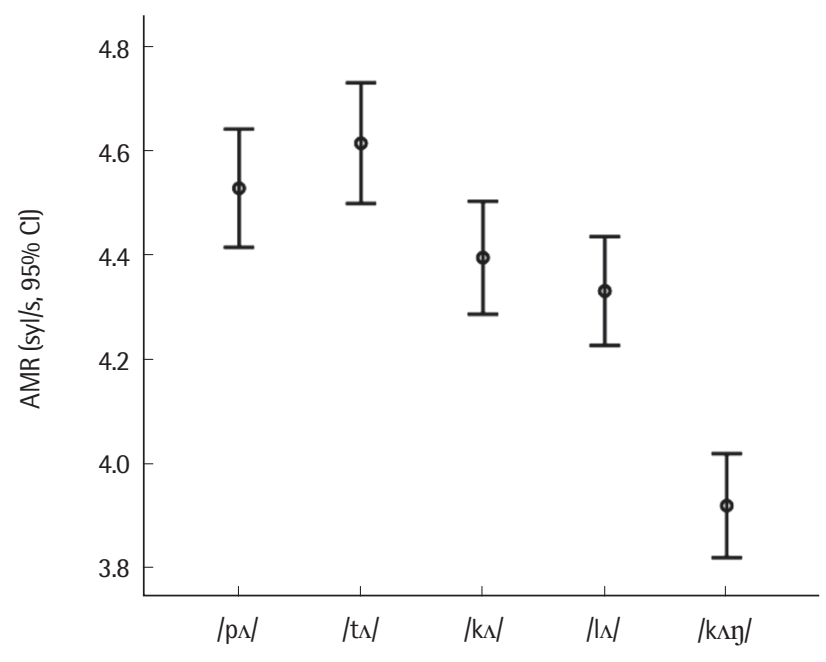

Figure 7. Alternative motion rate (AMR) of five syllables $(/ \mathrm{p} \Lambda /, / \mathrm{t} \Lambda /, / \mathrm{k} \Lambda /, / \mathrm{L} /$, and $/ \mathrm{k} \wedge \mathrm{y} / \mathrm{f}$. Error bar represents the standard deviation of the data.

6세는 8-12세의 각 연령 $(p<.05)$ 과, 7 세는 12 세 $(p=.020)$ 와 유의한 차이를 보였다. 또한 일음절에 따른 차이를 살펴보기 위한 사후검 정 결과, / 커/와/러/의 대응을 제외한 모든 일음절 간 $(p<.001)$ 에 유 의한차이가 있었다(Figure 7).

/퍼터커/의 SMR 전체 평균은 1.58 회/초 $(\mathrm{SD}=0.37)$ 였고, 남아는 1.62 회/초 $(\mathrm{SD}=0.37)$, 여아는 1.55 회/초 $(\mathrm{SD}=0.36)$ 였다. 성별과 연 령 간 상호작용이나 성별에 따른 유의한 차이는 없었으나 연령에 따라 유의한 차이를 보였다 $(F=19.710, p<.001)$. 사후검정 결과, 3 세는 5-12세의 각 연령 $(p<.001)$ 과, 4 세는 6-12세의 각 연령 $(p<.001)$ 과, 5 세는 8-12세의 각 연령 $(p<.01)$ 과 유의한 차이를 보였고, 6세와 7 세는 모두 11 세 $(p<.05)$ 와 12 세 $(p<.05)$ 와 유의하게 차이를 나타 냈으며, SMR도 연령이 증가할수록 증가하는 경향을 보인다(Figure 8).

\section{논의 및 결론}

본 연구는 정상 아동의 조음기관 구조와 기능의 이상 유무를 평 가하여 의사소통장애 아동의 말 중재를 위한 기초 자료로 사용될 수 있는 SMST-C의 표준화 작업을 목적으로 하였다. 이를 위해 정 상 발달 과정에 있는 학령전기 아동(3-6세) 114명(남아 53명, 여아 61 명)과 학령기 아동(7-12세) 122 명(남아 58 명, 여아 64 명)의 총 236 명(남아 111명, 여아 125명)을 대상으로 SMST-C를 실시하였다. 본 연구를 통해 산출된 결과는 다음과 같다.

SMST-C 총점수의 평균은 95.62점으로 그 범위가 80-100점이었 다. 성별과 연령에 따른 상호작용이 있었는데 총점수의 평균이 다

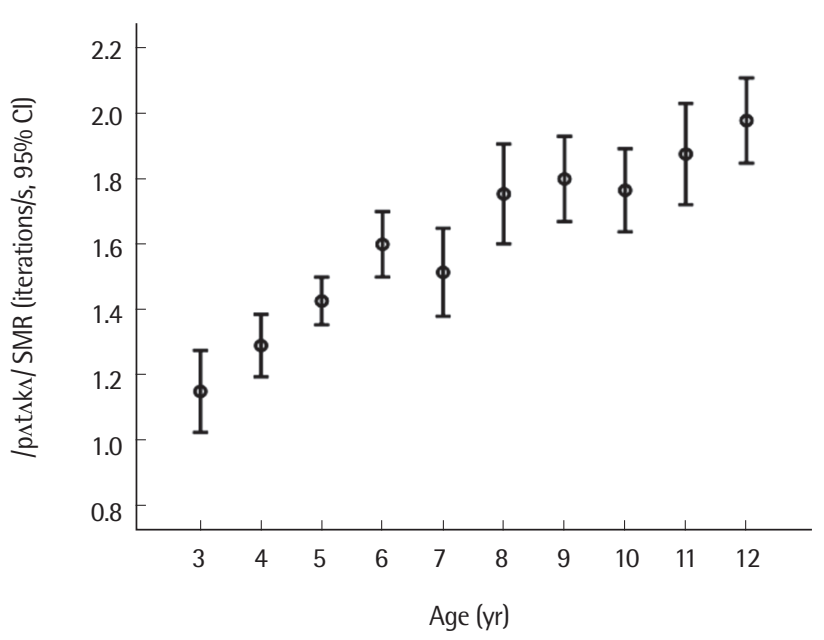

Figure 8. Sequential motion rates (SMR) of /pst $\mathrm{k} \Lambda /$ by age. Error bar represents the standard deviation of the data.

른 연령대에서는 여아가 남아에 비해 높은 반면, 6세, 7세 그리고 12 세에서는 남아가 여아에 비해 높았기 때문이다. 그러나 Figure 2와 같이 이 연령대의 $95 \%$ 신뢰구간을 살펴보면, 6 세 남아와 여아는 각 94.95-98.43점과 92.06-95.19점이었고, 7세 남아와 여아는 각 92.2496.43점과 92.19-95.81점이었으며, 12세 남아와 여아는 각 95.91100.66점과 95.06-99.80점으로 세 연령대 모두 남아와 여아 간의 95\% 신뢰구간이 중첩되어 나타났다. 이는 각 연령대에서 임상적으 로 남아가 여아에 비해 총점수가 높지 않음을 의미하는 것으로 성 별과 연령에 따른 유의한 상호작용이 나타났다고 볼 수 없다. 이와 더불어 3-12세 정상 발달 아동의 SMST-C 총점수는 성별이나 연령 에 따라서도 차이가 없으므로 총점수는 성별이나 연령별로 구분하 여 비교할 필요는 없는 것으로 보인다. 또한 SMST-C를 이용하여 3-6세 학령전기 아동의 조음기관 구조와 기능을 살펴본 선행연구 (Kim \& Kim, 2016)에서도 총점수의 평균이 93.82점, 범위가 81-100 점으로 성별이나 연령별에 따른 차이가 없어 본 연구와 동일한 결 과를 보였다.

총점수를 산출하는 하위 영역별로 살펴보면, ‘조음기관 구조.기 능' 영역은 최대 산출 가능한 범위가 0-60점으로, 본 연구에서는 평 균이 56.84점이었고 범위가 47-60점이었으며, 성별이나 연령에 따 른 차이는 없었다. 다만, 각 세부 항목을 자세히 살펴보았을 때, '조 음기관 구조·기능'에서 얼굴이나 입술의 경우에 심각한 비정상을 나타내는 0 점을 받은 경우는 없었으나, 혀의 구조에서 설소대의 길 이가 짧아 0 점을 받은 경우, 즉 혀를 치아와 입술 사이까지 내밀거 나 혀를 내밀었을 때 $\mathrm{W}$ 모양이 되는 아동이 총 8 명으로, 이 아동들 은 혀끝을 올려 치조에 대거나 혀끝을 경구개를 따라 뒤쪽으로 끌 
어당기는 혀의 기능 항목에서도 혀의 운동 범위가 제한되어 0 점 또 는 1 점을 받았다. 설소대의 길이와 관련한 혀의 길이는 혀의 운동에 영향을 미쳐 말소리 산출에 영향을 미칠 수 있기 때문에 이러한 아 동들의 발달 상황에 대해서 면밀히 살펴보아야 할 것이다.

또한 턱과 치아의 경우에는 중앙 앞니의 교합에서 턱의 좌우가 비대칭이거나 개방교합(openbite), 과개교합(deepbite), 수평피개교 합(overjet), 수직피개교합(overbite) 등이 관찰되어 0점을 받은 아 동이 15 명으로, 이러한 아동들은 치찰음이나 치조음의 이상을 초 래할 수 있다(Jeffrey, 2014; Kummer, 2014). 또한 치아의 맞물림 상 태를 나타내는 부정교합의 경우에도 II급과 III급 부정교합자가 22 명으로, 전체 대상자 236명 중 약 $9 \%$ 에 해당하는 아동이 부정교합 을 보였다. III급 부정교합의 경우 혀와 치조 간의 공간이 생겨 치찰 음의 오류가 발생할 수 있고(Bloomer, 1971), 하악의 돌출로 인해 혀의 위치가 낮아지는 구조적 변화가 동반되어 일부 모음의 오류가 발생할 수 있다(Kim, Yoo, Kim, \& Hong, 2009). II급 부정교합이 있는 경우에도 하악의 퇴축으로 발생한 상악과 하악 간의 공간으 로 인해 치찰음 산출 시 호기 산출로 인한 측방 혀짜래기 말이 산 출되거나 상악의 돌출로 혀끝이 상악 치조에 닿지 않아서 치찰음 을 포함한 치조음과 양순음 산출에 오류가 발생할 수 있다(Kummer, 2014; Park, Lee, \& Shon, 1997). 본 연구에서도 II급과 III급 부 정교합이 관찰된 아동 22 명 중 11 명이 / $/ \mathrm{s} /$ 와 /b/에서 왜곡을 보였다. 본 연구의 대상자들이 성장 발달하는 과정에 있는 아동이기 때문 에 중앙 앞니의 교합이나 부정교합이 이들의 말소리 산출의 지속 적 오류를 초래할 것이라고 단정 지을 수는 없으나 SMST-C와같은 조음기관의 구조나 기능의 선별검사를 통해 교합의 이상이 발견되 는 경우에는 추후 지속적인 관찰과 표준화된 조음 검사를 실시하 도록 권고하여야 할 것이다.

경구개 및 연구개 영역에서는 입천장의 높이가 너무 높거나 넓이 가 좁은 경우인 1 점 또는 0 점인 경우가 43 명으로 전체 대상자의 약 $18 \%$ 를 차지하였다. 이 중 높이와 넓이의 두 가지 모두 이상소견이 보 여 0 점을 받은 경우는 3 명으로, 이 경우에 치아의 구조나 기능에 이 상을 초래하여 결과적으로 말소리 산출에도 영향을 미칠 수 있으 므로(Cha, 1995; Chung et al., 2010) 추후 이들의 치아의 구조와 기 능의 변화 및 말소리의 이상 유무도 지속적으로 관찰할 필요가 있 다. 구개의 높이와 넓이는 연령이 증가할수록 높아지고 넓어지며, 일 반적으로 남아가 여아에 비해 구개가 높고 넓다고 하였다. 본 연구 에서 사용된 SMST-C는 선별검사로서 입천장의 높이와 넓이를 직 접 계측하지는 못했지만 SMST-C를 검사할 때 시각적으로 구개가 높이가 높거나 낮은 경우 또는 넓이가 넓거나 좁은 경우로 판단될 때 좀더 정밀한 검사와 계측을 통해 정확한 진단이 필요할 것이다.
구개편도가 육안으로 관찰될 만큼 비대해져 1점 또는 0 점을 받 은 아동의 수는 31 명으로 전체 대상자의 약 $13 \%$ 를 차지하였다. 이 들 중 7명이 중도로 비대해져 있었다. 구개편도의 비대는 구강호흡 을 유도할 뿐 아니라 음질에도 영향을 미치고, $\mathrm{DDK}$ 속도의 저하 및 치조마찰음의 치간음화와 같은 말소리장애를 유발할 수 있으므 로(Song, 2014) 아동의 조음기관의 구조와 기능을 평가할 때에는 구개편도의 상태를 평가하는 것이 필요하다.

경구개 및 연구개 평가 중 구개반사(교액반사, gag reflex)의 여부 를 평가하는 항목에서 양쪽 목구멍(구협궁, faucial pillars) 모두의 구개반사가 없는 경우가 전체 대상자의 $25 \%$ 에 해당하였다. 구개반 사가 없는 경우 조음기관의 비정상적 기능이라고 보기는 어렵지만 간혹 삼차신경, 설인신경 및 미주신경의 신경학적 손상이 동반될 때 발생할 수 있으므로 구개반사가 나타나지 않는 대상자의 경우는 다른 영역의 조음기관을 함께 평가함으로써 신경학적 이상의 유무 를 판별해야 할 것이다.

‘발성·음성·조음선별' 영역은 산출 가능한 0-16점 중 평균이 15.12점이었고 범위는 8-16점으로 성별이나 연령별로 상호작용이 나 각각의 주효과가 나타나지 않았는데, 음성의 경우 특정 성별이 나 연령에서만 음성장애가 발생하지 않는다는 점을 시사하며, 조 음선별은 본 연구의 대상자 선정 기준을 언어나 조음장애가 없는 아동으로 제한하였고 자음 습득연령에 따라 해당 연령에서 산출 될 수 없는 자음의 오류를 범하였을 때는 정상 조음으로 간주하였 기 때문에 나타난 결과로 보인다. 그러나 본 연구에서 26 명의 아동 이 1점인 ‘왜곡’으로 평가받아 조음장애로 진단받지는 않았어도 말 소리의 오류를 보이는 아동들이 전체 대상자의 $11 \%$ 에 해당하였다. 이러한 아동들은 단지 해당 연령의 자음습득 연령에 비해 늦을 수 도 있지만 조음장애로 발전될 가능성이 있기 때문에 조음장애가 의심되는 아동은 표준화된 조음검사를 통해 장애의 유무를 변별 해야한다.

'조음교대운동'은 $\mathrm{AMR}$ 과 $\mathrm{SMR}$ 을 측정할 때 $\mathrm{DDK}$ 의 조음규칙 성과 조음정확성을 살펴보는 영역으로, 최대 산출 가능한 0-24점 중 본 연구의 정상 아동들의 평균은 23.66점이었고, 범위가 18-24 점으로 성별과 연령에 따른 상호작용이 나타났다. 이는 다른 연령 대에서는 여아의 평균이 높은 반면 6세와 9세는 남아가 여아에 비 해 평균이 높게 나타난 결과일 수 있다. 그러나 $95 \%$ 신뢰구간이 6세 의 남아와 여아가 각 23.45-24.44점과 23.14-23.89점이었고, 9세의 남아와 여아는 23.57-24.45점과 22.80-23.81점으로 각 연령대에서 점수가 중첩되어 나타나므로 임상적으로 성별에 따라 의미가 있는 점수의 차이로 보기 어려워 남아와 여아 모두 학령전기나 학령기의 모든 연령대에 걸쳐 $\mathrm{DDK}$ 를 규칙적이고 정확하게 실시하였다고 볼 
수 있다. 또한 Figure 1을 살펴보면, $\mathrm{DDK}$ 점수의 차이가 남아의 경 우 3 세와 5 세의 평균이 낮고 범위가 넓다가 연령이 증가할수록 높 아지고 범위가 줄어든 반면, 여아는 연령에 따라 큰 차이가 없어 남 아의 경우에 3-5세까지 조음의 규칙성이나 조음의 정확성이 다소 낮은 반면 6세 이후부터는 어느 정도 규칙적이고 정확한 조음 운동 이 이루어진다고 볼 수 있다. 학령전기 아동을 대상으로 실시한 선 행연구(Kim \& Kim, 2016)에서도 성별과 연령 간의 유의한 상호작 용이 나타났는데, 이는 다른 연령대에 비해 5세 남아와 6세 여아가 다소 낮은 규칙성을 보였기 때문으로 보았다. 그러나 이 연구에서 도 이들과 다른 연령대 간의 $95 \%$ 신뢰구간이 모두 중첩되고 평균 차이가 낮아 모든 연령대에서 규칙적이고 정확한 $\mathrm{DDK}$ 를 실시하였 다고 평가하였다. 다만, 이 연구에서는 모든 학령전기의 모든 연령 대에서 여아가 남아에 비해 평균적으로 높은 점수를 보여 여아들 이 비교적 규칙적이고 정확하게 $\mathrm{DDK}$ 를 수행하였다고 하였으나 본 연구에서는 3-5세까지는 남아가 다소 낮고 넓은 범위의 조음규칙 성과 조음정확성을 보인 반면, 학령기에서는 여아와 남아 간의 차 이가 거의 나타나지 않아 조음 실수의 횟수가 연령이 증가할수록 감소한다는 연구의 결과와 유사하다(Sehr, 2013). 따라서 '조음교대 운동'을 평가할 때에는 반드시 학령전기와 학령기로 구분하여 살 펴보아야 하며, 검사 대상자의 해당 연령에 맞는 규준 점수와도 비 교할 필요가 있다.

MPT는 호흡과 발성 및 조음과 공명에 관여하는 근육 간의 협응 관계를 살펴볼 수 있는 말운동 평가 과제로서 본 연구에서의 전체 평균은 11.69 초였고 범위는 2.15-31.00초로 연령 간에 유의한 차이 를 보였다. 3세의 경우 평균 MPT가 7.30초(남아 7.05초, 여아 7.50 초)였다가 연령이 증가함에 따라 점차 증가하여 12 세에는 14.93 초 (남아 15.08초, 여아 14.78초)로, 남아와 여아 모두 연령이 증가함에 따라 MPT는 지속적으로 증가하는 경향을 보였다. 다만, 3-4세 간 (평균 8.06초), 5-8세 간(평균 10.94초), 9-12세(평균 15.16초) 간에 는 각각 차이가 없었고, 이 세 연령군 간에 MPT가 급격히 상승하 는 양상을 보였다. 따라서 3-12세 아동의 MPT는 이 세 연령군으로 만 구분하여 규준점수를 살펴보아도 무방하다고 볼 수 있다. 학령 전기 아동을 대상으로 한 국내연구들 $(\mathrm{Im}, 2014 ; \mathrm{Kim}, 2008$; Kim \& $\mathrm{Kim}, 2016)$ 에서도 본 연구결과와 같이 연령이 증가함에 따라 MPT 가 증가하였다. 그러나 학령기 아동들의 MPT를 살펴본 연구들 (Jeong, 2010; Lee, Choi, \& Sim, 2002; Park, 2004)은 대부분이 7-10 세 범위 내의 소수의 아동들을 대상으로 MPT의 전체 아동의 평균 만을 제시하고 있어 학령기 아동의 연령에 따른 MPT 변화나 특성 을 살펴보기는 어렵기 때문에 본 연구에서 학령기 아동의 연령별 $\mathrm{MPT}$ 특성을 살펴본 것은 매우 의미 있다고 할 수 있다. 이와 더불
어 본 연구에서는 선행연구들에서 제시된 연구결과들(Im, 2014; Kim \& Kim, 2016)과 마찬가지로 학령전기(3-6세) 아동들은 성별 에 따른 MPT의 차이가 없었을 뿐 아니라 학령기(7-12세) 아동들 또한 성별에 따라 MPT의 차이가 나타나지 않았다. 이는 학령전기 나 학령기 아동은 아직 성별에 따라 신체적 차이가 크지 않기 때문 에 MPT에 있어서도 차이가 나지 않는다고 할 수 있다. 따라서 3-12 세 아동의 MPT는 성별을 구분하지 않고 남아와 여아의 평균값을 규준점수로 사용하여도 될 것이다. 그러나 성인의 MPT는 남성이 22.73초, 여성이 18.49초로 성별 간에 유의한 차이가 있었는데 (Shin, Kim, Lee, \& Lee, 2008), 본 연구를 통해 측정된 아동의 MPT 와는 현저한 차이가 있어 아동기에는 MPT가 성별에 따라 차이가 나타나지 않지만 성인이 되어가면서 점차적인 신체 특성의 차이로 인해 성별에 따른 차이가 발생함을 알 수 있다. 이에 추후 연구에서 는 아동기와 성인기의 중간 단계인 청소년기의 성별에 따른 MPT의 차이를 살펴볼 필요가 있을 것이다.

읽기에서의 초당 음절수(syllables per second, SPS)를 측정한 말 속도는 연령에 따라 유의한 차이를 보였고, 연령이 증가함에 따라 말속도가 증가하는 것으로 나타났다. 성별에 따른 말속도는 유의 한 차이가 나타나지 않았다. 이는 선행연구들에서 이미 밝혀진 바 와 동일한 결과이다. 3-8세 아동을 대상으로 한 자발화 상에서의 말속도를 분석한 연구(Kim, Chang, \& Lee, 2006)에서는 연령이 1 년씩 증가됨에 따라 일관되게 말속도가 증가하는 양상을 보였고, 학령기 아동의 그림을 통한 자발화 상에서의 말속도를 측정한 연 구(Moon, 2014)에서도 학년이 높아질수록 말속도가 빨라지는 상 관관계를 보여 연령이 증가함에 따라 읽기 말속도나 자발화 말속도 모두 증가한다고 볼 수 있다. Figure 4 를 보면, 본 연구에서도 연령 이 1년씩 증가함에 따라 말속도가 일정한 비율로 증가하는 것을 알 수 있다. 따라서 읽기를 통한 말속도를 측정하여 평가할 때에는 1 년 의 연령 단위를 기준으로 제시된 규준점수와 비교하여야 할 것이 다. 또한 11세 아동의 평균 말속도가 5.59 SPS (남아 5.68, 여아 5.52) 였고, 12 세는 5.46 SPS (남아 5.35, 여아 5.57)로, 초등학교 6학년 아 동을 대상으로 읽기 말속도를 측정한 연구(Kim, 2017)에서의 남아 는 $5.23 \mathrm{SPS}$, 여아는 $5.56 \mathrm{SPS}$ 와 유사할 뿐 아니라 5 학년부터 말속 도가 크게 증가한다는 연구결과(Moon, 2014)와도 비슷한 양상을 보인다. 또한 이러한 측정값은 성인의 읽기 말속도를 측정한 연구 (Shin \& Han, 2003)에서 제시된 5.77 SPS와 유사한 값을 보이는데, 이는 고학년이 될수록 다양한 읽기자료를 접할뿐 아니라 효율적인 말하기 기술을 갖게 되어 말하는 속도가 급진적으로 증가하기 때 문에 초등학교 고학년이 되면 말하는 속도가 성인 수준에 도달한 다고 볼 수 있다(Ahn, Shin, \& Kwon, 2002). 
$\mathrm{DDK}$ 속도는 조음기관을 구성하는 근육들이 특정한 말소리를 산출하기 위해 규칙적이고 빠르게 반복하여 움직이는 운동 속도를 측정하는 것으로(Duffy, 2005), 말장애 유무를 평가하고 말장애 화 자들의 조음 능력을 알아보는 선별검사로 많이 사용된다(Freed, 2000; Sehr, 2013). 본 연구에서 살펴본 아동의 DDK 속도는 모든 일 음절의 AMR과 3음절의 SMR에서 연령이 증가함에 따라 증가하 며 성별에 따라서는 차이가 없었다. 다만 일음절과 연령 간의 상호 작용이 유의하게 나타났는데, 이는 연령마다 각 일음절의 AMR 순 서가 달라진 것에서 기인하지만 Figure 6을 보면 모든 일음절의 AMR 이 연령이 증가함에 따라 증가하는 추세를 보이고 있어 임상적으 로 큰 의미를 갖는다고 볼 수 없다. AMR은 음절마다 차이는 있지 만/퍼/,/터/, /커/, /러/의 경우 일반적으로 학령전기 아동은 3-4.5회/ 초, 학령기 아동은 4.5-5.5회/초의 속도를 산출하여 전체 평균이 4.5 회/초 정도였으며, SMR은 학령전기 아동이 1-1.5회/초, 학령기 아동이 1.5-2.0회/초의 속도로 전체 평균이 1.58회/초였다. 다만/겅/ 의 AMR은 다른 음절에 비해 다소 느린 속도를 보여 학령전기 아동 이 3-3.5회/초, 학령기 아동이 3.7-4.7회/초로 전체 평균이 3.92회/초 였다. 또한 AMR과 SMR 모두 Figures 5와 8에서 알 수 있듯이 연령 이 증가할수록 일관적으로 증가하는 양상을 보여 학령전기와 학령 기에 따라 구분된 규준점수를 사용할 수도 있지만 1년 단위의 연령 으로 구분된 규준점수를 사용하는 것이 더 합리적으로 보인다. 본 연구에서 제시된 학령전기 아동의 AMR과 SMR 속도의 평균은 선 행연구들에서 제시한 수치들과 유사하며(Choe \& Han, 1998; Kim, 2008; Kim \& Kim, 2016; Sehr, 2013), 학령기 아동의 AMR과 SMR 의 평균 또한 Choe와 $\operatorname{Han}$ (1998) 연구의 결과와 유사하였다. 성인 을 대상으로 측정한 DDK 속도는 /긍/을 제외한/퍼/, /터/, /커/, /러/ 의 $\mathrm{AMR}$ 은 6 회/초 이상이었고, /긍/의 $\mathrm{AMR}$ 은 5.5회/초 정도, $\mathrm{SMR}$ 은 2.56 회/초로, 본 연구에서 측정된 아동의 DDK 속도는 성인에 비 해 현저하게 느린 것을 알 수 있다.

조음위치에 따른 AMR 속도는 모든 연령에서/터/가 가장 빨랐 고, 그 다음으로 /퍼/, /커/, /러/, /겅/의 순으로 나타났으며, /커//러/ 간에만 유의한 차이가 없었고, 다른 음절 간에는 유의한 차이를 보 였다. 특히 /겅/은 모든 연령대에서 다른 모든 음절에 비해 가장 느 린 AMR을 보였는데, 이는 학령전기 아동을 대상으로 한 연구 (Kim \& Kim, 2016) 및 성인을 대상으로 한 연구(Shin et al., 2008) 와 동일한 결과로, 아동과 성인 모두 연구개음의 조음교대를 수행 하는 운동속도가 가장 느림을 알 수 있다. 즉 혀를 주된 조음기관으 로 사용하는 치경음을 산출할 때 가장 편안하고 빠르게 조음교대 를 수행할 수 있으며, 그 다음으로 조음점이 입술로부터 구강 뒤쪽 으로 갈수록 $\mathrm{DDK}$ 속도가 점차적으로 감소한다는 것을 알 수 있
다. 따라서 일반적으로 $\mathrm{DDK}$ 속도를 측정할 때/퍼/와 같은 양순음, /터/와 같은 치경음, /커/와 같은 연구개음의 CV 구조의 음절만을 사용하지 말고 /겅/과 같은 CVC 구조의 구강음과 비강음이 결합되 어 연인두 개폐 기전의 복잡한 말 기제 운동을 살펴볼 수 있는 음절 도 함께살펴볼 필요가 있음을 시사한다.

본 연구는 새롭게 개발된 SMST-C의 표준화를 위해 실시된 것으 로 제한점을 살펴보면, 각 연령대별로 남아와 여아의 표준화 점수 를 제시하기 위해서는 좀 더 많은 대상자를 포함시켜야 할 것이다. 또한 ‘조음기관 구조.기능'을 평가하는 항목 중 주관적인 평가가 이 루어지는 항목에 대한좀더 명확한 근거를 제시함으로써추후SMST$\mathrm{C}$ 를 사용하는 이용자들이 점수를 평가할 때 혼동이 되지 않도록 해야 할 것이다. 이와 더불어 다양한 의사소통장애 아동들을 대상 으로 SMST-C를 실시함으로써 정상군과 의사소통장애군 간의 조 음기관의 구조와 기능의 차이를 변별할 수 있는지를 확인하고, 의 사소통장애 유형과 중증도에 따라 어떠한 차이가 있는지를 비교할 필요가 있다.

결론적으로 본 연구는 학령전기와 학령기 정상 아동의 조음기관 구조와 기능을 선별하여 평가할 수 있는 검사도구를 통해 표준화 작업을 실시하여 다양한 연령의 조음기관 구조와 기능, $\mathrm{MPT}$, 말속 도 및 $\mathrm{DDK}$ 속도의 정상치를 제시함으로써 임상현장에서 언어재 활사나 관계 전문가들이 손쉽게 사용이 가능하며 조음기관의 구 조나 기능을 살펴보지 못함으로 초래되는 언어중재의 오류를 사전 에 예방할수 있을 것으로 판단된다.

\section{REFERENCES}

Ahn, J. B., Shin, M. S., \& Kwon, D. H. (2002). The study of speech rate in normal-speaking adults and children. Speech Sciences, 9, 93-103.

Bloomer, H. (1971). Speech defects associated with dental malocclusion. In L. E. Travis (Ed.), Handbook of speech pathology and audiology (pp. 715-766). New York, NY: Meredith Corporation.

Cha, K. S. (1995). Orthodontic diagnosis. Seoul: Kuk Je D.M. Publishing Co.

Choe, J., \& Han, J. S. (1998). Diadochokinetic rate of normal children and adults: a preliminary study. Korean Journal of Communication \& Disorders, 3, 183-194.

Chung, B. Y., Lim, Y. J., Kim, M. J., Nam, S. E., Lee, S. P., \& Kwon, H. B. (2010). The effect of palatal height on the Korean vowels. The Journal of Korean Academy of Prosthodontics, 48, 69-74.

Duffy, J. R. (2005). Motor speech disorders: substrates, differential diagnosis, and management (2nd ed.). St Louis, MO: Mosby. 
Freed, D. B. (2000). Motor speech disorders: diagnosis \& treatment. San Diego, CA: Singular.

Im, K. (2014). Voice acoustic characteristics of preschool children (Master's thesis). Catholic University of Daegu, Gyeongsan, Korea.

Jeffrey, C. P. (2014). Orthognathic surgery: principles \& practice. St. Louis, MO: Elsevier Saunders.

Jeong, K. (2010). Acoustic characteristics of voice of Taekwondo training children and normal children (Master's thesis). Daegu University, Gyeongsan, Korea.

Kent, R. D., Kent, J. F., \& Rosenbek, J. C. (1987). Maximum performance tests of speech production. Journal of Speech and Hearing Disorders, 52, 367-387.

Kim, B. (2017). Characteristics of speech rate perception according to upper grade in elementary school (Master's thesis). Myongji University, Seoul, Korea.

Kim, M. J., \& Pae, S. (2005). The percentage of consonants correct and the ages of consonantal acquisition for 'Korean-Test of Articulation for Children (K-TAC)'. Speech Sciences, 12, 139-149.

Kim, S. Y. (2008). Maximum phonation time and diadochokinetic rate in normal Korean children (Master's thesis). Yonsei University, Seoul, Korea.

Kim, T. K., Chang, K. H., \& Lee, P. Y. (2006). Increase in speaking rate by 3-8-year-old Korean children. Speech Sciences, 13, 83-95.

Kim, Y. H., Yoo, H. J., Kim, W. Y., \& Hong, J. R. (2009). An acoustic analysis on the pronunciation of Korean vowels in patient with class III malocclusion. Journal of the Korean Association of Oral and Maxillofacial Surgeons, 35, 221-228.

Kim, Y. S., \& Kim, J. O. (2016). A preliminary study to develop a Speech Mechanism Screening Test for preschool children. Journal of Speech-Language \& Hearing Disorders, 25, 105-123.

Kim, Y. T. (1996). Comparative study of the phonological processes between the normal and the articulation-disordered children. Journal of Special Education, 12, 211-235.
Kim, Y. T., \& Shin, M. J. (2004). Urimal Test of Articulation and Phonology (U-TAP). Seoul, Korea: Hakjisa

Kim, Y. T., Hong, G. H., Kim, K. H., Jang, H. S., \& Lee, J. Y. (2009). Receptive \& expressive vocabulary test (REVT). Seoul: Seoul Community Rehabilitation Center.

Kummer, A. W. (2014). Cleft palate and craniofacial anomalies: effects on speech and resonance (3rd ed.). Clifton Park, NY: Delmar/Cengage Learning.

Lee, E. K., Choi, H. S., \& Sim, H. S. (2002). Speech breathing in children with vocal nodules. Korean Journal of Communication \& Disorders, 7, 107-120.

Moon, J. E. (2014). A study on school-age children's speech rate and characteristics of disfluency depending on the grade level (Master's thesis). Daegu University, Gyeongsan, Korea.

Park, Y. (2004). A comparative study of didochokinetic in children with spastic cerebral palsy and normal children, using Praat program: with children of school age as central figure (Master's thesis). Yongin University, Yongin, Korea.

Park, Y. C., Lee, S. H., \& Shon, D. S. (1997). An acoustic analysis of pronunciation in children with Angle's Class II Div. 1 malocclusion. The Journal of the Korean Academy of Pediatric Dentistry, 24, 95-111.

Sehr, K. H. (2013). The study of diadochokinetic (DDK) rate and accuracy in typically developing children. Journal of Academia-Industrial Technology, 14, 321-327.

Shin, M., \& Han, S. J. (2003). A study of speech rate and fluency in normal speakers. Speech Sciences, 10, 159-168.

Shin, M., Kim, J., Lee, S., \& Lee, S. (2008). A preliminary study of developing Korean Oro-motor Mechanism Screening Examination (KOMSE) in normal adults. Speech Sciences, 4, 169-186.

Shin, M., Kim, J., Lee, S., \& Lee, S. (2009). Speech Mechanism Screening Test (SMST). Seoul: Hakjisa.

Song, Y. (2014). Comparison of speech motor function, articulation, and phonological characteristics of children with and without palatine tonsil hypertrophy. Communication Sciences \& Disorders, 19, 540-550. 
Appendix 1. SMST와 SMST-C 검사 항목 비교

\begin{tabular}{|c|c|c|c|c|}
\hline \multirow{2}{*}{ 영역 } & \multicolumn{2}{|c|}{ SMST } & \multicolumn{2}{|c|}{ SMST-C } \\
\hline & 항목 & 점수 & 항목 & 점수 \\
\hline \multirow[t]{7}{*}{ 조음기관 구조·기능 } & 얼굴(2) & 구조: 13항목(26점) & 얼굴(3) & 구조: 14항목(28점) \\
\hline & 입술(5) & 기능: 17항목(34점) & 입술(5) & 기능: 16항목(32점) \\
\hline & 혀(8) & & 혀(8) & \\
\hline & 턱과 치아(4) & & 턱과 치아(4) & \\
\hline & 경구개 및 연구개(6) & & 경구개 및 연구개(6) & \\
\hline & 인두(2) & & 인두(1) & \\
\hline & 호흡(3) & & 호흡(3) & \\
\hline \multicolumn{5}{|l|}{ 발성·음성·조음선별 } \\
\hline \multirow[t]{2}{*}{ 발성 및음성 } & $\begin{array}{l}\text { 음도, 음강, 음색(과제: MPT, } \\
\text { 자발화, 읽기카드) }\end{array}$ & 3항목(12점) & $\begin{array}{l}\text { 음도, 음강, 음색(과제: MPT, } \\
\text { 자발화, 그림카드/읽기카드) }\end{array}$ & 3항목(12점) \\
\hline & 최대연장발성(MPT) & & 최대연장발성(MPT) & \\
\hline 조음선별 & 자음정확성: ᄅ, ᄉ, ㅈ & 1항목 & $\begin{array}{l}\text { 자음정확성 } \\
\text { 학령전기: 어두초성자음 } \\
\text { 학령기: ㄹ, ㅅ, ㅈ }\end{array}$ & 1항목(4점) \\
\hline 말속도 & 말속도(과제: 읽기카드) & & 말속도(과제: 읽기카드) & \\
\hline \multirow[t]{4}{*}{ 조음교대운동 } & 조음규칙성 & 7항목(14점) & 조음규칙성 & 6항목(12점) \\
\hline & 조음정확성 & 7항목(14점) & 조음정확성 & 6항목(12점) \\
\hline & AMR: 퍼, 터, 커, 러, 긍, 아 & & AMR: 퍼, 터, 커, 러, 겅 & \\
\hline & SMR: 퍼터커 & & SMR: 퍼터커 & \\
\hline
\end{tabular}

SMST-C=Speech Mechanism Screening Test for Children. 
Appendix 2. 성별과 연령별 SMST-C의 영역별 점수 및 총점수

\begin{tabular}{|c|c|c|c|c|c|c|c|}
\hline & \multirow{2}{*}{ 연령 } & \multicolumn{2}{|c|}{ 남아 } & \multicolumn{2}{|c|}{ 여아 } & \multicolumn{2}{|c|}{ 총 } \\
\hline & & 평균 & 표준편차 & 평균 & 표준편차 & 평균 & 표준편차 \\
\hline \multirow{11}{*}{ 조음기관 구조·기능 } & 3 & 56.22 & 3.63 & 55.45 & 3.56 & 55.80 & 3.52 \\
\hline & 4 & 57.70 & 1.75 & 58.00 & 1.79 & 57.81 & 1.74 \\
\hline & 5 & 55.64 & 3.17 & 57.91 & 1.76 & 57.18 & 2.50 \\
\hline & 6 & 57.46 & 1.45 & 55.38 & 3.05 & 56.31 & 2.65 \\
\hline & 7 & 55.56 & 2.13 & 55.25 & 2.80 & 55.38 & 2.48 \\
\hline & 8 & 56.00 & 2.83 & 56.46 & 2.93 & 56.25 & 2.83 \\
\hline & 9 & 57.50 & 1.58 & 58.33 & 2.12 & 57.89 & 1.85 \\
\hline & 10 & 57.36 & 3.38 & 58.58 & 1.38 & 58.00 & 2.56 \\
\hline & 11 & 55.40 & 4.58 & 55.82 & 3.31 & 55.62 & 3.87 \\
\hline & 12 & 58.57 & 2.30 & 57.71 & 2.63 & 58.14 & 2.41 \\
\hline & 소계 & 56.80 & 2.82 & 56.87 & 2.79 & 56.84 & 2.80 \\
\hline \multirow[t]{11}{*}{ 발성·음성·조음선별 } & 3 & 14.89 & 1.05 & 15.27 & 1.62 & 15.10 & 1.37 \\
\hline & 4 & 15.10 & 1.21 & 15.09 & 1.38 & 15.10 & 1.25 \\
\hline & 5 & 14.55 & 1.57 & 14.96 & 1.58 & 14.82 & 1.57 \\
\hline & 6 & 15.38 & 1.71 & 14.75 & 1.77 & 15.03 & 1.74 \\
\hline & 7 & 15.11 & 1.05 & 14.83 & 2.33 & 14.95 & 1.86 \\
\hline & 8 & 14.73 & 2.41 & 15.38 & 0.96 & 15.08 & 1.77 \\
\hline & 9 & 15.20 & 1.03 & 14.89 & 2.67 & 15.05 & 1.93 \\
\hline & 10 & 14.55 & 2.02 & 15.83 & 0.58 & 15.22 & 1.57 \\
\hline & 11 & 15.60 & 0.84 & 15.45 & 0.93 & 15.52 & 0.87 \\
\hline & 12 & 15.71 & 0.76 & 15.71 & 0.76 & 15.71 & 0.73 \\
\hline & 소계 & 15.06 & 1.47 & 15.17 & 1.57 & 15.12 & 1.52 \\
\hline \multirow[t]{11}{*}{ 조음교대운동 } & 3 & 22.67 & 1.50 & 23.73 & 0.65 & 23.25 & 1.21 \\
\hline & 4 & 23.80 & 0.41 & 23.82 & 0.60 & 23.81 & 0.48 \\
\hline & 5 & 22.91 & 1.87 & 23.78 & 0.52 & 23.50 & 1.19 \\
\hline & 6 & 23.85 & 0.38 & 23.50 & 0.82 & 23.66 & 0.67 \\
\hline & 7 & 23.67 & 0.50 & 23.92 & 0.29 & 23.81 & 0.40 \\
\hline & 8 & 23.73 & 0.47 & 23.54 & 0.78 & 23.63 & 0.65 \\
\hline & 9 & 24.00 & 0.00 & 23.33 & 1.00 & 23.68 & 0.75 \\
\hline & 10 & 23.55 & 0.69 & 23.42 & 0.79 & 23.48 & 0.73 \\
\hline & 11 & 23.90 & 0.32 & 24.00 & 0.00 & 23.95 & 0.22 \\
\hline & 12 & 24.00 & 0.00 & 24.00 & 0.00 & 24.00 & 0.00 \\
\hline & 소계 & 23.62 & 0.89 & 23.70 & 0.65 & 23.66 & 0.77 \\
\hline \multirow[t]{11}{*}{ 총점수 } & 3 & 93.78 & 3.77 & 94.45 & 3.42 & 94.15 & 3.50 \\
\hline & 4 & 96.60 & 2.44 & 96.91 & 1.22 & 96.71 & 2.07 \\
\hline & 5 & 93.09 & 3.42 & 96.65 & 2.77 & 95.50 & 3.40 \\
\hline & 6 & 96.69 & 2.25 & 93.63 & 4.50 & 95.00 & 3.93 \\
\hline & 7 & 94.33 & 2.92 & 94.00 & 4.13 & 94.14 & 3.58 \\
\hline & 8 & 94.45 & 3.21 & 95.38 & 3.57 & 94.96 & 3.37 \\
\hline & 9 & 96.70 & 1.89 & 96.56 & 3.64 & 96.63 & 2.77 \\
\hline & 10 & 95.45 & 3.45 & 97.83 & 1.80 & 96.70 & 2.91 \\
\hline & 11 & 94.90 & 4.56 & 95.27 & 3.29 & 95.10 & 3.85 \\
\hline & 12 & 98.29 & 2.21 & 97.43 & 2.94 & 97.86 & 2.54 \\
\hline & 합계 & 95.49 & 3.26 & 95.74 & 3.47 & 95.62 & 3.37 \\
\hline
\end{tabular}

SMST-C=Speech Mechanism Screening Test for Children. 
Appendix 3. 성별과 연령별 MPT, 말속도 및 DDK 속도

\begin{tabular}{|c|c|c|c|c|c|c|c|c|}
\hline \multirow{2}{*}{ 영역 } & \multirow{2}{*}{ 음절 } & \multirow{2}{*}{ 연령 } & \multicolumn{2}{|c|}{ 남아 } & \multicolumn{2}{|c|}{ 여아 } & \multicolumn{2}{|c|}{ 총 } \\
\hline & & & 평균 & 표준편차 & 평균 & 표준편차 & 평균 & 표준편차 \\
\hline \multirow[t]{11}{*}{ MPT(초) } & & 3 & 7.05 & 2.91 & 7.50 & 5.48 & 7.30 & 4.41 \\
\hline & & 4 & 8.91 & 4.33 & 7.91 & 3.60 & 8.56 & 4.05 \\
\hline & & 5 & 10.59 & 8.25 & 10.87 & 6.31 & 10.78 & 6.87 \\
\hline & & 6 & 11.36 & 4.49 & 11.25 & 6.08 & 11.30 & 5.34 \\
\hline & & 7 & 11.86 & 4.34 & 9.23 & 2.95 & 10.36 & 3.76 \\
\hline & & 8 & 11.65 & 5.28 & 10.85 & 3.66 & 11.22 & 4.39 \\
\hline & & 9 & 16.30 & 7.23 & 14.59 & 6.83 & 15.49 & 6.90 \\
\hline & & 10 & 12.71 & 3.34 & 15.27 & 3.84 & 14.05 & 3.76 \\
\hline & & 11 & 18.09 & 5.76 & 14.53 & 5.66 & 16.23 & 5.86 \\
\hline & & 12 & 15.08 & 5.81 & 14.78 & 8.25 & 14.93 & 6.86 \\
\hline & & 소계 & 11.98 & 5.98 & 11.43 & 5.83 & 11.69 & 5.89 \\
\hline \multirow[t]{8}{*}{ 말속도(음절/초) } & & 6 & 3.92 & 1.43 & 3.97 & 1.03 & 3.94 & 1.18 \\
\hline & & 7 & 3.79 & 0.39 & 4.25 & 0.37 & 4.07 & 0.43 \\
\hline & & 8 & 4.32 & 0.82 & 5.08 & 0.72 & 4.73 & 0.84 \\
\hline & & 9 & 4.86 & 0.36 & 5.17 & 0.98 & 5.01 & 0.72 \\
\hline & & 10 & 5.06 & 0.82 & 5.11 & 0.69 & 5.09 & 0.74 \\
\hline & & 11 & 5.68 & 1.17 & 5.52 & 0.94 & 5.59 & 1.02 \\
\hline & & 12 & 5.35 & 0.72 & 5.57 & 1.22 & 5.46 & 0.97 \\
\hline & & 소계 & 4.68 & 1.10 & 4.83 & 1.09 & 4.76 & 1.09 \\
\hline \multirow{33}{*}{$\begin{array}{l}\text { DDK 속도: AMR } \\
\text { (음절/초) }\end{array}$} & /퍼/ & 3 & 3.48 & 0.67 & 3.66 & 0.94 & 3.58 & 0.81 \\
\hline & & 4 & 4.06 & 0.67 & 3.65 & 0.60 & 3.92 & 0.67 \\
\hline & & 5 & 4.21 & 0.62 & 4.03 & 0.73 & 4.09 & 0.69 \\
\hline & & 6 & 4.58 & 0.59 & 4.21 & 0.62 & 4.38 & 0.62 \\
\hline & & 7 & 4.69 & 0.37 & 4.38 & 0.71 & 4.51 & 0.60 \\
\hline & & 8 & 5.05 & 0.52 & 4.90 & 0.67 & 4.97 & 0.60 \\
\hline & & 9 & 5.30 & 0.57 & 5.00 & 0.76 & 5.16 & 0.67 \\
\hline & & 10 & 4.57 & 0.54 & 5.30 & 0.78 & 4.95 & 0.76 \\
\hline & & 11 & 5.22 & 1.02 & 5.14 & 0.54 & 5.18 & 0.78 \\
\hline & & 12 & 5.30 & 0.73 & 5.34 & 0.97 & 5.32 & 0.82 \\
\hline & & 소계 & 4.58 & 0.83 & 4.48 & 0.92 & 4.53 & 0.88 \\
\hline & /터/ & 3 & 3.50 & 0.74 & 3.49 & 0.86 & 3.50 & 0.79 \\
\hline & & 4 & 4.20 & 0.77 & 3.76 & 0.51 & 4.05 & 0.71 \\
\hline & & 5 & 4.45 & 0.53 & 4.02 & 0.67 & 4.16 & 0.66 \\
\hline & & 6 & 4.74 & 0.63 & 4.34 & 0.63 & 4.52 & 0.65 \\
\hline & & 7 & 4.77 & 0.51 & 4.75 & 0.65 & 4.76 & 0.58 \\
\hline & & 8 & 4.98 & 0.46 & 5.15 & 0.65 & 5.08 & 0.57 \\
\hline & & 9 & 5.47 & 0.67 & 5.13 & 0.84 & 5.31 & 0.75 \\
\hline & & 10 & 4.83 & 0.78 & 5.33 & 0.87 & 5.09 & 0.85 \\
\hline & & 11 & 5.17 & 0.90 & 5.05 & 0.57 & 5.10 & 0.73 \\
\hline & & 12 & 5.49 & 0.59 & 5.36 & 0.90 & 5.42 & 0.73 \\
\hline & & 소계 & 4.70 & 0.85 & 4.55 & 0.93 & 4.62 & 0.89 \\
\hline & /커/ & 3 & 3.27 & 0.53 & 3.54 & 0.83 & 3.42 & 0.71 \\
\hline & & 4 & 3.93 & 0.67 & 3.52 & 0.46 & 3.78 & 0.62 \\
\hline & & 5 & 4.28 & 0.59 & 3.91 & 0.69 & 4.03 & 0.67 \\
\hline & & 6 & 4.52 & 0.48 & 3.99 & 0.65 & 4.23 & 0.63 \\
\hline & & 7 & 4.36 & 0.53 & 4.30 & 0.80 & 4.32 & 0.68 \\
\hline & & 8 & 4.92 & 0.47 & 4.89 & 0.63 & 4.90 & 0.55 \\
\hline & & 9 & 5.09 & 0.58 & 4.75 & 0.74 & 4.94 & 0.66 \\
\hline & & 10 & 4.65 & 0.59 & 5.01 & 1.00 & 4.84 & 0.83 \\
\hline & & 11 & 4.84 & 0.75 & 4.87 & 0.48 & 4.86 & 0.61 \\
\hline & & 12 & 5.33 & 0.60 & 5.29 & 0.81 & 5.31 & 0.68 \\
\hline & & 합계 & 4.46 & 0.78 & 4.32 & 0.90 & 4.38 & 0.85 \\
\hline
\end{tabular}


Appendix 3. Continued

\begin{tabular}{|c|c|c|c|c|c|c|c|c|}
\hline \multirow{2}{*}{ 영역 } & \multirow{2}{*}{ 음절 } & \multirow{2}{*}{ 연령 } & \multicolumn{2}{|c|}{ 남아 } & \multicolumn{2}{|c|}{ 여아 } & \multicolumn{2}{|c|}{ 총 } \\
\hline & & & 평균 & 표준편차 & 평균 & 표준편차 & 평균 & 표준편차 \\
\hline & /러/ & 3 & 3.20 & 0.55 & 3.29 & 0.42 & 3.25 & 0.47 \\
\hline & & 4 & 3.64 & 0.66 & 3.55 & 0.61 & 3.61 & 0.63 \\
\hline & & 5 & 4.15 & 0.55 & 3.96 & 0.57 & 4.02 & 0.57 \\
\hline & & 6 & 4.32 & 0.61 & 4.21 & 0.59 & 4.26 & 0.59 \\
\hline & & 7 & 4.70 & 0.45 & 4.48 & 1.03 & 4.58 & 0.82 \\
\hline & & 8 & 4.75 & 0.53 & 5.08 & 0.38 & 4.93 & 0.47 \\
\hline & & 9 & 4.95 & 0.37 & 4.51 & 0.78 & 4.74 & 0.62 \\
\hline & & 10 & 4.75 & 0.43 & 5.08 & 0.75 & 4.92 & 0.63 \\
\hline & & 11 & 4.69 & 0.55 & 4.58 & 0.50 & 4.63 & 0.51 \\
\hline & & 12 & 4.81 & 0.72 & 5.06 & 0.92 & 4.94 & 0.80 \\
\hline & & 합계 & 4.33 & 0.77 & 4.33 & 0.86 & 4.33 & 0.81 \\
\hline & /겅/ & 3 & 3.00 & 0.69 & 3.03 & 0.43 & 3.02 & 0.54 \\
\hline & & 4 & 3.50 & 0.65 & 3.44 & 0.34 & 3.48 & 0.56 \\
\hline & & 5 & 3.69 & 0.62 & 3.50 & 0.58 & 3.56 & 0.59 \\
\hline & & 6 & 4.00 & 0.61 & 3.54 & 0.58 & 3.74 & 0.63 \\
\hline & & 7 & 3.79 & 0.50 & 3.81 & 0.72 & 3.80 & 0.62 \\
\hline & & 8 & 4.34 & 0.48 & 4.25 & 0.38 & 4.29 & 0.43 \\
\hline & & 9 & 4.75 & 0.35 & 4.38 & 0.65 & 4.57 & 0.53 \\
\hline & & 10 & 4.21 & 0.43 & 4.52 & 0.77 & 4.37 & 0.64 \\
\hline & & 11 & 4.24 & 0.76 & 4.45 & 0.51 & 4.35 & 0.63 \\
\hline & & 12 & 4.64 & 1.32 & 4.74 & 0.61 & 4.69 & 0.99 \\
\hline & & 합계 & 3.97 & 0.79 & 3.88 & 0.76 & 3.92 & 0.77 \\
\hline \multirow{11}{*}{$\begin{array}{l}\text { DDK 속도: SMR } \\
\text { (음절/초) }\end{array}$} & /퍼터커/ & 3 & 1.16 & 0.32 & 1.15 & 0.23 & 1.15 & 0.27 \\
\hline & & 4 & 1.32 & 0.29 & 1.24 & 0.19 & 1.29 & 0.26 \\
\hline & & 5 & 1.43 & 0.13 & 1.43 & 0.24 & 1.43 & 0.21 \\
\hline & & 6 & 1.72 & 0.26 & 1.50 & 0.23 & 1.60 & 0.26 \\
\hline & & 7 & 1.60 & 0.28 & 1.45 & 0.30 & 1.51 & 0.30 \\
\hline & & 8 & 1.81 & 0.34 & 1.71 & 0.39 & 1.75 & 0.36 \\
\hline & & 9 & 1.93 & 0.24 & 1.66 & 0.24 & 1.80 & 0.27 \\
\hline & & 10 & 1.66 & 0.16 & 1.86 & 0.36 & 1.77 & 0.29 \\
\hline & & 11 & 1.96 & 0.32 & 1.80 & 0.35 & 1.88 & 0.34 \\
\hline & & 12 & 1.93 & 0.27 & 2.03 & 0.18 & 1.98 & 0.23 \\
\hline & & 합계 & 1.62 & 0.37 & 1.55 & 0.36 & 1.58 & 0.37 \\
\hline
\end{tabular}

DDK=diadochokinesis; $M T P=$ maximum phonation time; $\mathrm{AMR}=$ alternative motion rate; $\mathrm{SMR}=$ sequential motion rate. 


\section{국문초록}

\section{아동용 조음기관 구조 및 기능 선별검사: 3-12세 정상 발달 아동의 수행 특성 평가 김재옥 $\cdot$ 신문자 ${ }^{2} \cdot$ 송윤경 3 \\ 1강남대학교 교육대학원 언어치료교육전공, ${ }^{2}$ 조선대학교 언어치료학과, ${ }^{3}$ 동명대학교 언어치료학과}

배경 및 목적: 본 연구는 정상 발달 아동에게 ‘아동용 조음기관 구조 및 기능 선별검사(Speech Mechanism Screening Test for Children, SMST-C)'를 실시하여 성별과 연령별 표준화된 점수를 제시하고자 하였다. 방법: 만 3-12세 236명(남아 111명, 여아 125명)의 정상 발달 아동을 대상으로 SMST-C를 실시하여 조음기관 구조·기능, 발성·음성·조음선별, 조음교대운동으로 이루어진 총점수와 최대발 성지속시간(maximum phonation time, MPT), 말속도 그리고 /퍼/, /터/, /커/, /리/, /겅/, 5 개 일음절의 교대운동속도(alternative motion rate, AMR)와/퍼터커/의 일련운동속도(sequential motion rate, SMR)의 DDK 속도를 측정한 뒤 성별과 연령에 따른 차이의 유의성을 검증하였다. 결과: SMST-C의 총점수는 성별과 연령에 따라 유의한 차이가 없었다. MPT와 말속도는 연령이 증가함에 따라 유의하게 증가하였다. 모든 일음절의 $\mathrm{AMR}$ 와 SMR 또한 연령이 증가함에 따라 유의하게 증가하였다. 이와 더불어 치경음인 /터/의 AMR이 다른 일음절들에 비해 가장 빨랐고, 연구개음인 /겅/의 AMR이 가장 느렸다. 논의 및 결론: 본 연구는 SMST-C를 이용한 아동의 조음기전에 관한 정상 기초 자료를 제공하였고, SMST-C는 언어재활사와 관련 전문가들이 비정상적인 조음 기전을 보이는 아동을 선별하는 데 도 움을 줄 것으로 보인다.

핵심어: 아동용 조음기관 구조 및 기능 선별검사, 최대발성지속시간, 말속도, 조음교대운동속도

이 연구는 2013년도 정부(교육과학기술부)의 재원으로 한국연구재단의 지원을 받아 연구되었고(No. NRF-2013S1A5A8025388), 2015년 제 4 회 한국언어청각임상학회·한국언어치료학회 공동 학술대회에서 발표한 내용의 일부를 포함함.

\section{참고문헌}

김민정, 배소영(2005). ‘아동용 조음검사’를 이용한 연령별 자음정확도와 우리말 자음의 습득연령. 음성과학, 12, 139-149.

김보람(2017). 초등학교 고학년 말속도에 따른 말속도 지각의 특성. 명지대학교 대학원 석사학위논문.

김수연(2008). 유년층의 최대발성시간 및 조음교대운동속도. 연세대학교 대학원 석사학위논문.

김양선, 김재옥(2016). 아동용 조음기관 구조 및 기능 선별검사 제작을 위한 학령전기 아동 대상 예비조사. 언어치료연구, 25, 105-123.

김영태(1996). 조음장애아와 정상아의 음운변동 패턴에 관한 비교 연구. 특수교육논총, 12, 211-235.

김영태, 신문자(2004). 우리말조음·음운평가(U-TAP). 서울: 학지사.

김영태, 홍경훈, 김경희, 장혜성, 이주연(2009). 수용·표현어휘력검사(REVT). 서울: 서울장애인종합복지관.

김영호, 유현지, 김휘영, 홍종락(2009). III급 부정교합 환자의 한국어 모음 발음에 관한 음향학적 분석. 대한구강악안면외과학회지, 35, 221-228.

김태경, 장경희, 이필영(2006). 한국어 발화 속도의 연령별 증가에 관한 연구. 음성과학, 13, 83-95.

문지은(2014). 학령기 아동의 학년에 따른 말 속도와 비유창성 특성. 대구대학교 대학원 석사학위논문.

박양미(2004). Praat 프로그램을 이용한 경직형 뇌성마비아동과 일반아동의 교대운동 비교 연구: 학령기 아동을 중심으로. 용인대학교 대학원 석사 학위논문.

박윤정, 이상훈, 손동수(1997). Angle씨 II급 1류 부정교합아동의 발음에 관한 음향학적 연구. 대한소아치과학회지, 24, 95-111.

서경희(2013). 취학 전 아동의 정상구어 발달 조음교대운동 특성. 한국산학기술학회논문지, 14, 321-327.

송윤경(2014). 구개편도비대 아동과 일반 아동의 말운동 기능 및 조음음운 특성 비교. 언어청각장애연구, 19, 540-550.

신문자, 김재옥, 이수복, 이소연(2008). 정상성인의 조음기관 구조 및 기능선별검사 제작을 위한 예비연구. 음성과학, 4, 169-186.

신문자, 김재옥, 이수복, 이소연(2009). 조음기관 구조·기능 선별검사. 서울: 학지사. 
신문자, 한숙자(2003). 정상 성인의 말속도 및 유창성 연구. 음성과학, 10, 159-168.

안종복, 신명선, 권도하 (2002). 정상 성인 및 아동의 구어속도에 관한 연구. 음성과학, 9, 93-103.

이은경, 최홍식, 심현섭(2002). 성대결절 아동의 호흡양상에 관한 연구. 언어청각장애연구, 7, 107-120.

임경선(2014). 학령전기 아동 음성의 음향학적 특성. 대구가톨릭대학교 대학원 석사학위논문.

정경희(2010). 태권도 수련아동과 일반아동의 음성특성 비교. 대구대학교 대학원 석사학위논문.

정보윤, 임영준, 김명주, 남신은, 이승표, 권호범(2010). 구개의 높이가 한국어 모음 발음에 미치는 효과에 관한 연구. 대한치과보철학회지, 48, 69-74.

차경석(1995). 교정진단학. 서울: 국제치의학출판사.

최정윤, 한진순(1998). 정상아동과 성인의 교대운동속도에 관한 연구. 언어청각장애연구, 3, 183-194. 